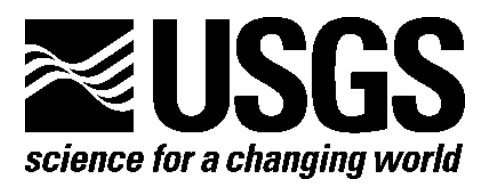

The work described in this report was performed in cooperation with the U.S. Department of Energy and the U.S. Bureau of Ocean Energy Management.

\title{
Cruise Report for P1-13-LA, U.S. Geological Survey Gas Hydrates Research Cruise, R/V Pelican April 18 to May 3, 2013, Deepwater Gulf of Mexico
}

By Seth S. Haines, Patrick E. Hart, Carolyn D. Ruppel, Thomas O'Brien, Wayne Baldwin, Jenny White, Eric Moore, Pete Dal Ferro, and Peter Lemmond

Open-File Report 2014-1080 


\section{U.S. Department of the Interior \\ SALLY JEWELL, Secretary}

\section{U.S. Geological Survey \\ Suzette M. Kimball, Acting Director}

U.S. Geological Survey, Reston, Virginia: 2014

For more information on the USGS-the Federal source for science about the Earth,

its natural and living resources, natural hazards, and the environment-visit

http://www.usgs.gov or call 1-888-ASK-USGS

For an overview of USGS information products, including maps, imagery, and publications, visit $h$ ttp://www.usgs.gov/pubprod

To order this and other USGS information products, visit $h$ ttp://store.usgs.gov

Suggested citation:

Haines, S.S., Hart, P.E., Ruppel, C.D., O'Brien, Thomas, Baldwin, Wayne, White, Jenny, Moore, Eric, Dal Ferro, Pete, and Lemmond, Peter, 2014, Cruise report for P1-13-LA, U.S. Geological Survey gas hydrates research cruise, R/V Pelican April 18 to May 3, 2013, deepwater Gulf of Mexico:

U.S. Geological Survey Open-File Report 2014-1080, 33 p., http://dx.doi.org/10.3133/ofr20141080.

ISSN 2331-1258 (online)

Any use of trade, firm, or product names is for descriptive purposes only and does not imply endorsement by the U.S. Government.

Although this information product, for the most part, is in the public domain, it also may contain copyrighted materials as noted in the text. Permission to reproduce copyrighted items must be secured from the copyright owner. 


\section{Contents}

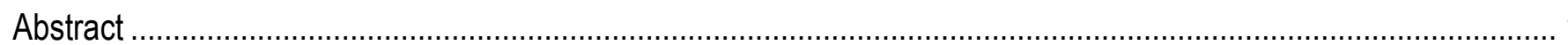

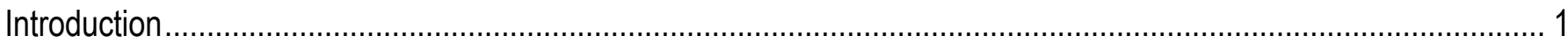

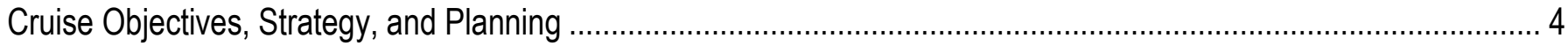

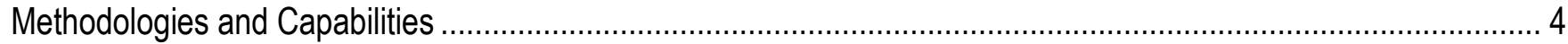

Seismic Streamer and Air Guns ......................................................................................................... 4

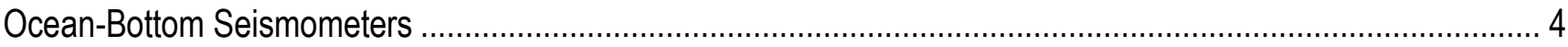

Study Sites

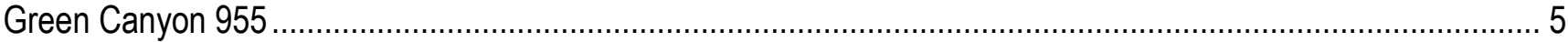

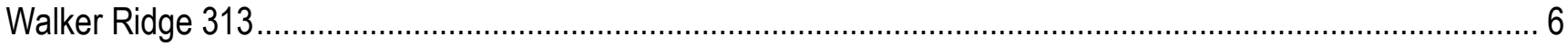

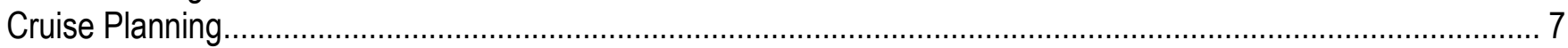

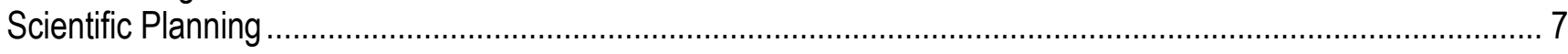

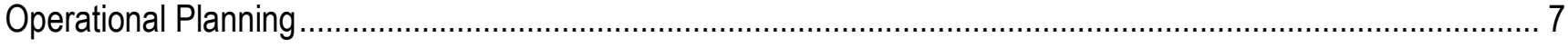

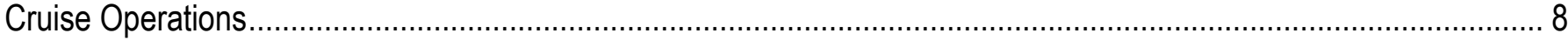

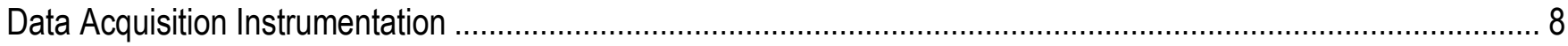

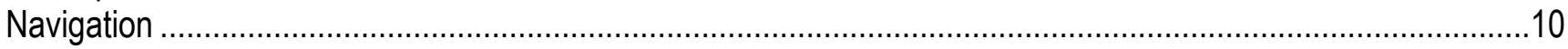

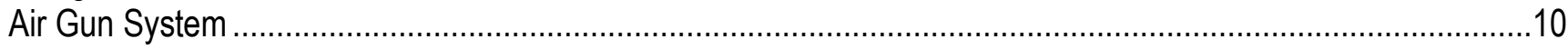

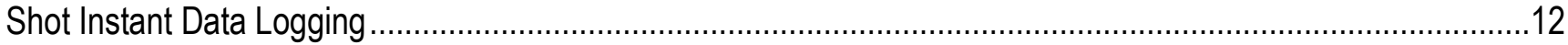

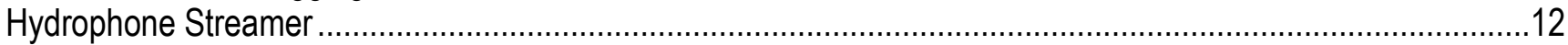

Woods Hole Oceanographic Institute Ocean-Bottom Seismometer ................................................................13

Multichannel Seismic Data Recording and Processing ..........................................................................16

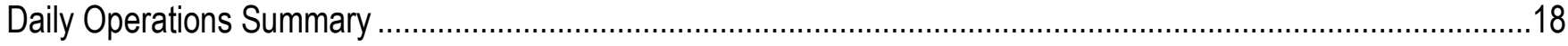

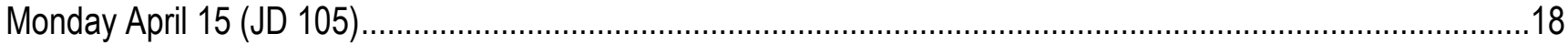

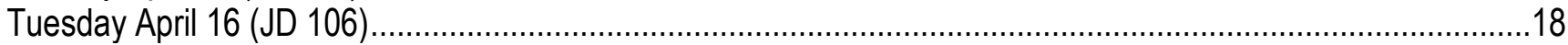

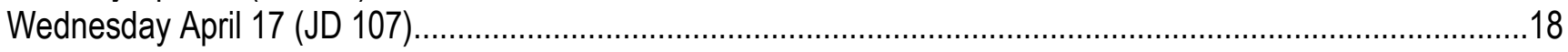

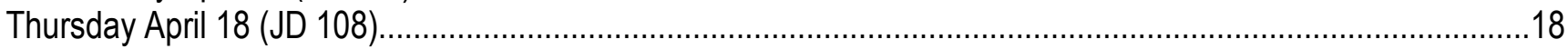

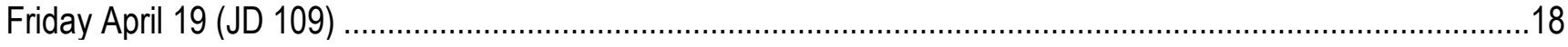

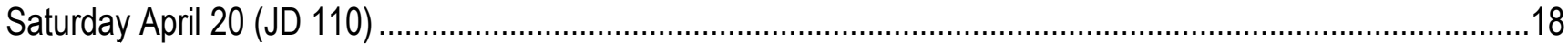

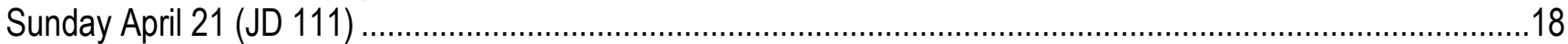

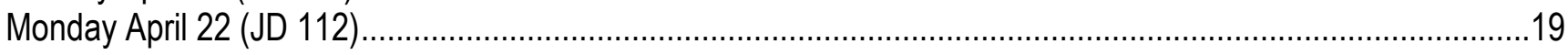

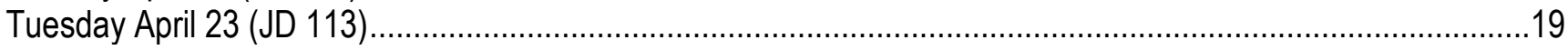

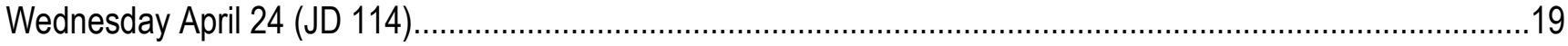

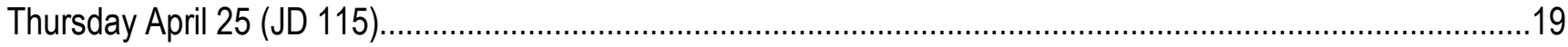

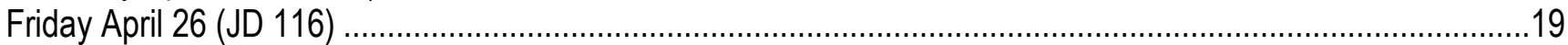

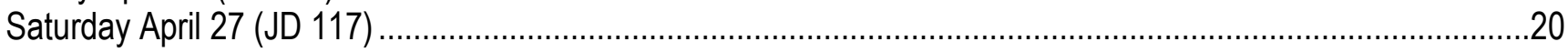

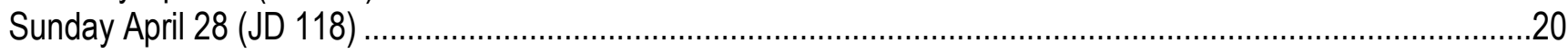

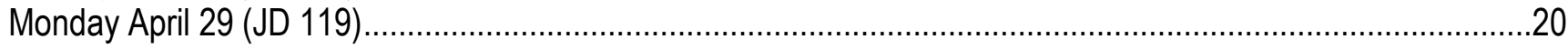

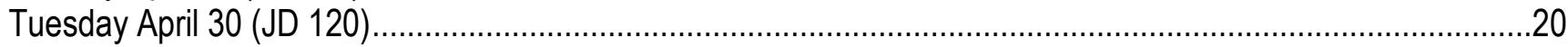

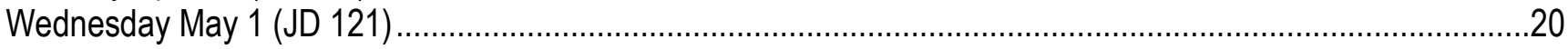

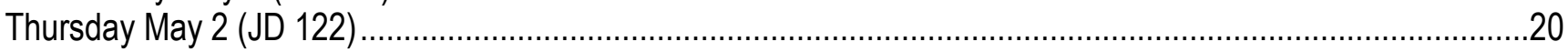

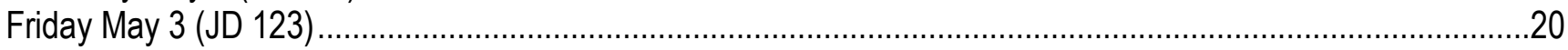

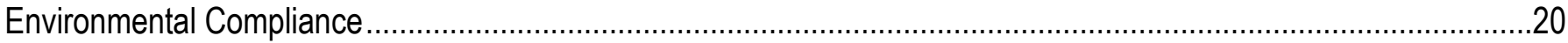

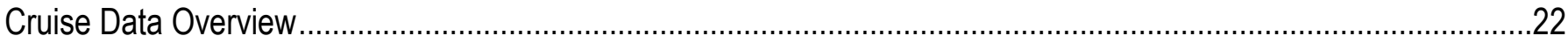

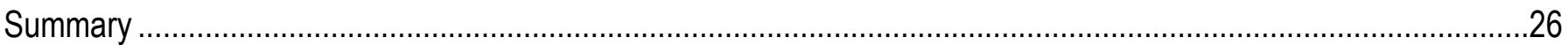

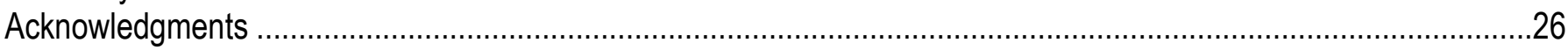

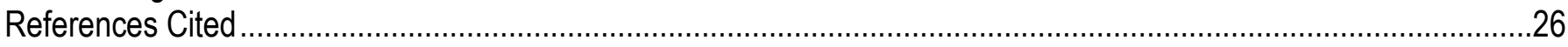

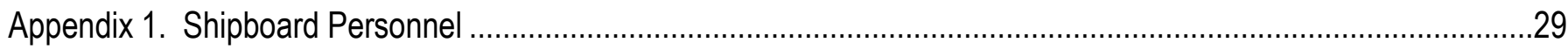

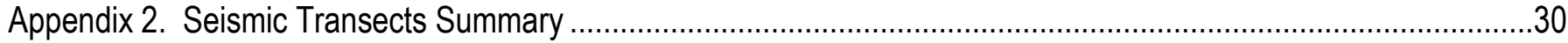




\section{Figures}

Figure 1. Map showing Gulf of Mexico bathymetry, Cocodrie, Louisiana, and Green Canyon 955 and Walker Ridge 313 study sites.

Figure 2. Photo of $R / V$ Pelican fantail from 01 deck during multichannel seismic data acquisition .......................... 9

Figure 3. Pete Dal Ferro, USGS, supervising GI-gun deployment from RN Pelican stern .................................... 11

Figure 4. Eric Moore and Wayne Baldwin, USGS, retrieving GeoEel multichannel streamer with attached Geospace depth control bird

Figure 5. Tim Kane and Peter Lemmond, Woods Hole Oceanographic Institute, deploying OBS with attached anchor plate from RN Pelican starboard-side main deck. Photo courtesy of Patrick Hart ................................... 14

Figure 6. Shipboard processing of Walker Ridge 313 seismic line WR228 …............................................... 17

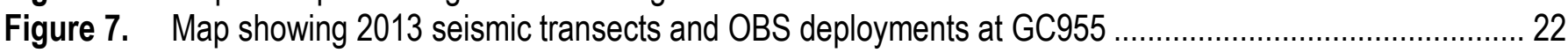

Figure 8. Zoomed map showing 2013 seismic transects and OBS deployments at GC955 …............................. 23

Figure 9. Map showing 2013 seismic transects and OBS deployments at WR313 ............................................. 24

Figure 10. Zoomed map showing 2013 seismic transects and OBS deployments at WR313 including line

WR228 in red for which processed data are shown in figure 6

\section{Tables}

Table 1-1. The following individuals made up the shipboard party for cruise P1-13-LA

Table 2-1. This table lists the seismic transect lines and provides some relevant information for each line

\section{Conversion Factors}

Inch/Pound to SI

\begin{tabular}{lll}
\hline \multicolumn{1}{c}{ Multiply } & \multicolumn{1}{c}{ By } & \multicolumn{1}{c}{ To obtain } \\
\hline inch (in.) & Length & \\
foot (ft) & 2.54 & centimeter $(\mathrm{cm})$ \\
mile, nautical (nmi) & 0.3048 & meter $(\mathrm{m})$ \\
\hline & 1.852 & kilometer $(\mathrm{km})$ \\
\hline cubic inch $\left(\mathrm{in}^{3}\right)$ & Volume & \\
cubic foot $\left(\mathrm{ft}^{3}\right)$ & 0.01639 & liter $(\mathrm{L})$ \\
\hline
\end{tabular}

SI to Inch/Pound

\begin{tabular}{|c|c|c|}
\hline Multiply & By & To obtain \\
\hline \multicolumn{3}{|c|}{ Length } \\
\hline meter $(\mathrm{m})$ & 3.281 & foot $(\mathrm{ft})$ \\
\hline kilometer (km) & 0.6214 & mile (mi) \\
\hline kilometer $(\mathrm{km})$ & 0.5400 & mile, nautical (nmi) \\
\hline
\end{tabular}




\section{Abbreviations}

$\begin{array}{ll}\text { ADCP } & \text { Acoustic Doppler Current Profiler } \\ \text { BOEM } & \text { Bureau of Ocean Energy Management } \\ \text { CMP } & \text { common mid-point } \\ \text { DOE } & \text { Department of Energy } \\ \text { EA } & \text { Environmental Assessment } \\ \text { ESA } & \text { Endangered Species Act } \\ \text { FONSI } & \text { Finding of No Significant Impact } \\ \text { GI-guns } & \text { Generator-injector air guns } \\ \text { IHA } & \text { Incidental Harassment Authorization } \\ \text { IHAA } & \text { IHA application } \\ \text { JD } & \text { Julian day } \\ \text { JIP } & \text { Joint Industry Project }\end{array}$

LUMCON Louisiana Universities Marine Consortium

LWD logging while drilling

MCS multichannel seismic

MMC Marine Mammal Commission

MMPA Marine Mammal Protection Act

NEPA National Environmental Protection Act

NGO Non-governmental organization

NMFS National Marine Fisheries Service

NOAA National Oceanic and Atmospheric Administration

NSF National Science Foundation

OBS ocean-bottom seismometer

OBSIP OBS Instrument Pool

OPR Office of Protected Resources (NOAA)

PEIS Programmatic Environmental Impact Statement

PSVO Protected Species Visual Observer

rms root-mean-square

ROD Record of Decision

UNOLS Universities National Oceanographic Laboratories System

WHOI Woods Hole Oceanographic Institute 


\title{
Cruise Report for P1-13-LA, U.S. Geological Survey Gas Hydrates Research Cruise, R/V Pelican April 18 to May 3, 2013, Deepwater Gulf of Mexico
}

\author{
By Seth S. Haines, ${ }^{1}$ Patrick E. Hart, ${ }^{2}$ Carolyn Ruppel, ${ }^{3}$ Thomas O'Brien, ${ }^{4}$ Wayne Baldwin, ${ }^{5}$ Jenny White, ${ }^{6}$
} Eric Moore, ${ }^{7}$ Pete Dal Ferro, ${ }^{8}$ and Peter Lemmond ${ }^{9}$

\begin{abstract}
The U.S. Geological Survey led a seismic acquisition cruise in the Gulf of Mexico from April 18 to May 3, 2013, with the objectives of (1) achieving improved imaging and characterization at two established gas hydrate study sites, and (2) refining geophysical methods for gas hydrate characterization in other locations. We conducted this acquisition aboard the $R / V$ Pelican, and used a pair of 105/105-cubic-inch generator/injector air guns to provide seismic energy that we recorded using a 450-meter 72-channel digital hydrophone streamer and 25 multicomponent ocean-bottom seismometers.

In the area of lease block Green Canyon 955, we deployed 21 ocean-bottom seismometers and acquired approximately 400 kilometers of high-resolution two-dimensional streamer seismic data in a grid with line spacing as small as 50 meters and along radial lines that provide source offsets up to 10 kilometers and diverse azimuths for the ocean-bottom seismometers. In the area of lease block Walker Ridge 313, we deployed 25 ocean-bottom seismometers and acquired approximately 450 kilometers of streamer seismic data in a grid pattern with line spacing as small as 250 meters and along radial lines that provide source offsets up to 10 kilometers for the ocean-bottom seismometers. The data acquisition effort was conducted safely and met the scientific objectives.

\section{Introduction}

Gas hydrates are present in arctic and marine settings worldwide, and are of interest because of their possible role in global climate change, their potential as a substantial energy resource, and their status as a possible drilling hazard. Between 2001 and 2013, the Gulf of Mexico Gas Hydrates Joint

\footnotetext{
${ }^{1}$ U.S. Geological Survey Central Energy Resources Science Center, Denver, Colorado.

${ }^{2}$ U.S. Geological Survey Pacific Coastal and Marine Science Center, Santa Cruz, California.

${ }^{3}$ U.S. Geological Survey Woods Hole Coastal and Marine Science Center, Woods Hole, Massachusetts.

${ }^{4}$ U.S. Geological Survey Woods Hole Coastal and Marine Science Center, Woods Hole, Massachusetts.

${ }^{5}$ U.S. Geological Survey Woods Hole Coastal and Marine Science Center, Woods Hole, Massachusetts.

${ }^{6}$ U.S. Geological Survey Pacific Coastal and Marine Science Center, Santa Cruz, California.

${ }^{7}$ U.S. Geological Survey Woods Hole Coastal and Marine Science Center, Woods Hole, Massachusetts.

${ }^{8}$ U.S. Geological Survey Pacific Coastal and Marine Science Center, Santa Cruz, California.

${ }^{9}$ Woods Hole Oceanographic Institute, Woods Hole, Massachusetts.
} 
Industry Program (JIP) brought together industry, government, and academic groups to study gas hydrate accumulations in the Gulf of Mexico (detailed information on the JIP is available at http://www.netl.doe.gov/technologies/oilgas/FutureSupply/MethaneHydrates/projects/DOEProjects/CharHydGOM-41330.html). Major accomplishments included the 2005 JIP Leg I drilling, coring, and logging expedition in lease blocks Atwater Valley 13 and 14, and at Keathley Canyon 151 (Collett, 2005; Claypool, 2006; Ruppel and others, 2008), and the 2009 JIP Leg II logging-while-drilling (LWD) expedition in lease blocks Green Canyon (GC) 955, Walker Ridge (WR) 313, and Alaminos Canyon 21 (Boswell and others, 2009; Cook and others, 2009). The LWD data from GC955 indicate thick (as much as 30 meters [m]) sand layers containing gas hydrate concentrations as high as 80 percent, and the data from WR313 indicate a sequence of thinner sands with gas hydrate saturations locally as high as 90 percent (Boswell and others, 2012a; Collett and others, 2012).

The GC955 and WR313 JIP II sites (fig. 1) host reservoir-grade gas hydrate accumulations and represent world-class gas hydrate study sites within a long-established petroleum province. The LWD data provide highly detailed characterization at the boreholes, and available industry three-dimensional (3D) seismic data facilitate interpretations between and away from the boreholes. Important questions remain regarding lithology and gas hydrate characterization away from the LWD boreholes, as well as structural and stratigraphic details that cannot be resolved with the 3D seismic data. Together, the U.S. Geological Survey (USGS), the U.S. Department of Energy (DOE) and the U.S. Bureau of Ocean Energy Management (BOEM) recognized the necessity for acquiring new geophysical data at WR313 and GC955 to fill these knowledge gaps. In particular, it was recognized that multicomponent seismic data would provide much needed constraint on the compressional $(\mathrm{P})$ wave and shear $(\mathrm{S})$ wave seismic velocities as well as PP reflection and P-to-S converted wave images. In addition, dedicated highresolution hydrophone streamer seismic data would enable substantially more detailed interpretations of the structural and stratigraphic features associated with the gas and gas hydrate systems. A USGS-led seismic acquisition cruise emerged as the preferred approach for accomplishing these goals. 


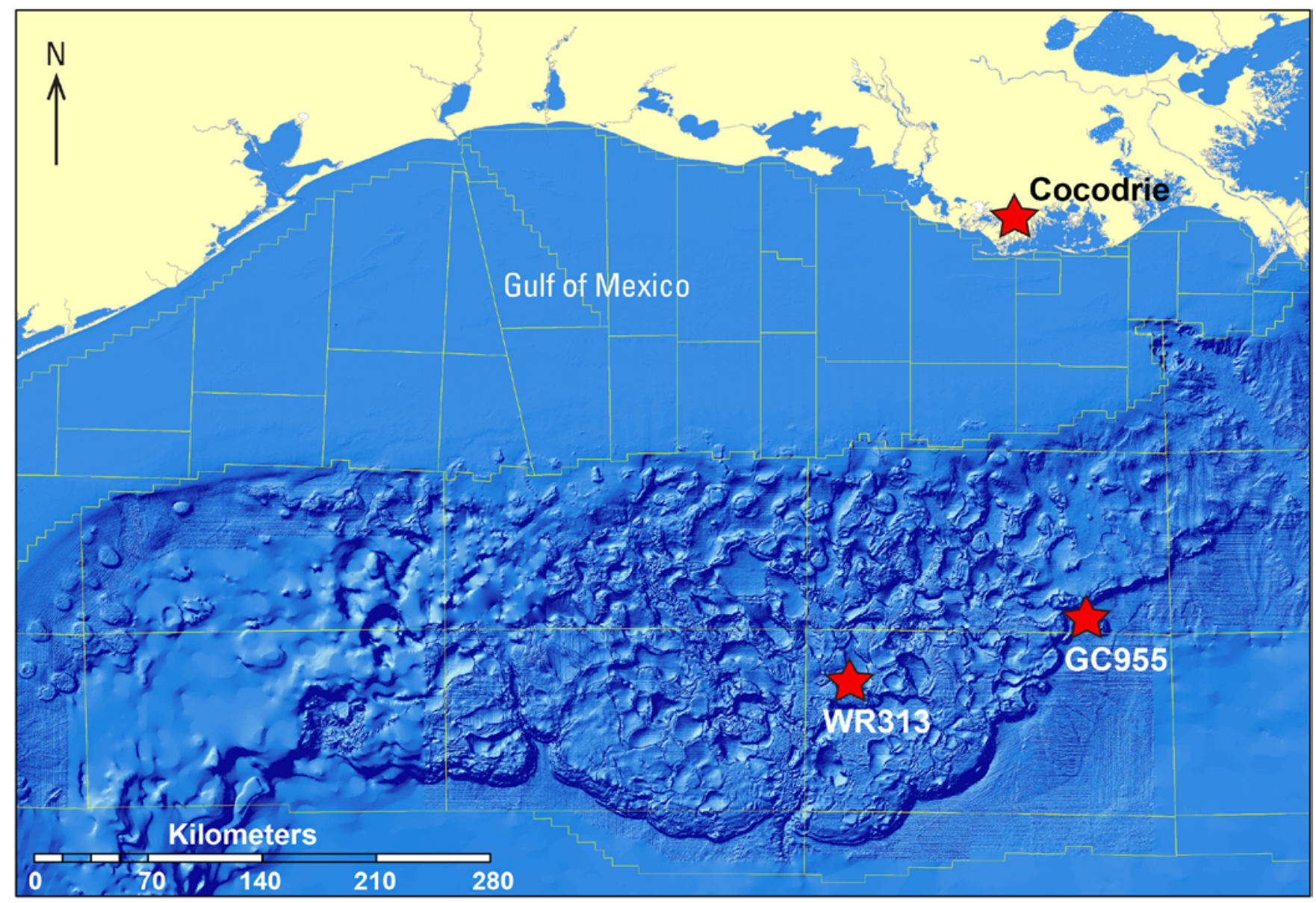

Figure 1. Map showing Gulf of Mexico bathymetry, Cocodrie, Louisiana, and Green Canyon 955 and Walker Ridge 313 study sites.

The USGS designed a science strategy in close cooperation with BOEM and DOE scientists, and determined a logistical and operational plan to acquire a seismic dataset comprised of (1) highresolution streamer seismic data to address structural and stratigraphic questions, and (2) ocean-bottom seismometer (OBS) data to answer many characterization questions and to serve as a pilot study for possible future industry-led multicomponent data acquisition. Funding for the acquisition program was provided by the DOE, the BOEM, and the USGS. We used USGS-owned equipment to the extent possible, augmented by borrowed and leased items as necessary. On April 18, 2013, we sailed from Cocodrie, Louisiana, aboard the $R / V$ Pelican, a Universities National Oceanographic Laboratories System (UNOLS) vessel owned and operated by the Louisiana Universities Marine Consortium (LUMCON). We returned on May 3, 2013, having conducted safe operations and effective data acquisition, and having accomplished our primary scientific goals.

In this document we provide an operational synopsis of the April/May 2013 cruise aboard the $R / V$ Pelican. We first describe the cruise objectives and planning, and then describe the cruise operations including avoidance of effects on marine mammals. Finally, we provide examples of the acquired data and a summary of the cruise accomplishments. 


\section{Cruise Objectives, Strategy, and Planning}

\section{Methodologies and Capabilities}

The $2013 R / V$ Pelican seismic cruise made use of two distinct, but highly complementary, seismic methodologies. A digital hydrophone streamer towed behind the vessel and OBS deployed on the seafloor recorded seismic energy produced by air guns towed directly behind the vessel. In this section, we provide a brief description of these methodologies; in the "Data Acquisition Instrumentation" section we provide a detailed description of the specific equipment used.

\section{Seismic Streamer and Air Guns}

Seismic reflection methods provide images of the subsurface through processing and analysis of seismic energy that reflects off of interfaces in the Earth. Typically, the seismic sources are controlled to create a particular signal at a particular time, and the energy from repeated seismic sources is recorded by a number of seismic receivers to achieve redundancy that is used to improve the image quality. In a marine setting, this is achieved in a variety of ways, but for the purpose of imaging sedimentary layers hundreds and thousands of meters below the seafloor we chose to create seismic energy with air guns, which release a pulse of highly compressed air in a controlled and repeatable manner. Depending on size and design, air guns can create energy with various frequency and power characteristics. Generatorinjector (GI) air guns (henceforth referred to as "GI-guns") contain two chambers designed to minimize the reverberatory bubble pulse in the seismic source wavelet. The "injector" chamber of the GI-gun is timed to discharge 0.020 to 0.040 seconds $(\mathrm{sec})$ after the "generator" chamber to suppress the collapsing bubble.

To record data with the redundancy needed for high-quality images, marine seismic-reflection data generally are acquired with hydrophone streamers containing a considerable number of individual hydrophones that are towed behind the vessel a few meters below the sea surface. Depending on budget and survey priorities, streamers can be as long as 10 kilometers $(\mathrm{km})$ or more. The use of multiple hydrophone streamers, generally towed in parallel, enables the acquisition of 3D data. We reviewed the seismic acquisition technologies appropriate to our science objectives, including high-resolution 3D options, and determined that a single 500-m, 72-channel, hydrophone streamer was ideal for our budget and survey goals. This type of technology often is referred to as multichannel seismic (MCS) acquisition.

The data from our hydrophone streamer were intended to provide images to a depth of at least $1 \mathrm{~km}$ below the seafloor with resolution on the order of $10 \mathrm{~m}$. In comparison, existing industry seismic data were optimized to image layers up to $10 \mathrm{~km}$ below the seafloor and thus required larger seismic sources that provide resolution on the order of $50 \mathrm{~m}$. We designed the two-dimensional (2D) data acquisition to facilitate imaging and analysis of previously undetected faults and other gas migration conduits, along with fine-scale layers that may control the distribution of gas and gas hydrate.

\section{Ocean-Bottom Seismometers}

Whereas hydrophone streamer data inherently are limited to recording $\mathrm{P}$ waves (the only type of seismic body wave that can propagate through fluids such as water), ocean-bottom recording enables the recording and analysis of $\mathrm{S}$ waves in addition to $\mathrm{P}$ waves. Upward-propagating converted $\mathrm{S}$ waves are created when $\mathrm{P}$ waves from air guns or other sources encounter strata below the seafloor. $\mathrm{kS}$ and $\mathrm{P}$ waves are sensitive to different properties and thus can provide complementary subsurface characterization. Both wave types can be recorded at the seafloor by ocean-bottom cables (OBC) and 
OBS. OBC contain multiple hydrophones and 1- or 3-component geophones and are towed along the seafloor by seismic vessels; the use of OBC generally is limited to water depths of less than approximately $1 \mathrm{~km}$. OBS typically contain a hydrophone and a 3-component geophone along with a recording apparatus and batteries. An array of OBS can be deployed on the seafloor in virtually any depth of water and can be left to record for a period of time before being retrieved. In typical modern industry work, OBS (also referred to as ocean-bottom nodes) are deployed in arrays of hundreds or thousands that are placed precisely on the seafloor by remotely operated vehicles (ROV). For the 2013 $R / V$ Pelican survey, we opted for the standard academic approach of deploying tens of strategically placed OBS by free-fall from the sea surface.

We acquired OBS data at our study sites with the aim of creating PP (reflected) and PS (converted) wave images beneath each instrument. Another key product of the OBS data processing will be P- and S-wave seismic velocity profiles beneath each instrument; these will provide valuable subsurface characterization and a linkage to the LWD data at each site. In addition, P-mirror imaging (Ronen and others, 2005; Dash and others, 2009) will provide PP reflection images over a much larger area than standard processing approaches, and refraction analysis can provide broad-area, but lowresolution, velocity models.

\section{Study Sites}

\section{Green Canyon 955}

GC955 is located in a structurally complex area on the edge of the abyssal plain, approximately $250 \mathrm{~km}$ south of Cocodrie, La. The water depth is approximately 2,000 m, and the main gas hydrate target layers are thick Pleistocene channel/levee sands that are between 400 and $500 \mathrm{~m}$ below the seafloor (Boswell and others, 2012a). Pre-drilling analysis of available seismic data suggested a heterogeneous distribution of gas and gas hydrate within coarse-grained sediments near the bottom of the gas hydrate stability zone (Hutchinson and others, 2009a), and this was confirmed by LWD data from three JIP II wells drilled at GC955 (Guerin and others, 2009; Boswell and others, 2009; Collett and others, 2012).

The area of primary interest at GC955 is a structurally complex four-way closure structure that was penetrated by two JIP II LWD wells. Well GC955-H is located on the flank of the structure, targeting a small ( 2 square kilometers $\left.\left[\mathrm{km}^{2}\right]\right)$ fault block that was predicted, and confirmed, to contain a thick, high-saturation, gas hydrate sand. Shallower in the section, well GC955-H penetrated a layer of fracture-filling gas hydrate amid fine-grained sediments between 250 and $350 \mathrm{~m}$ below the seafloor. Well GC955-Q is located near the high point of the structure, targeting a set of seismic amplitude anomalies that were predicted to represent a highly complex zone potentially hosting free gas. This assessment was confirmed by LWD data that indicate the upper part of the target sand layer to be highly saturated with gas hydrate and drilling data that indicate highly pressurized gas beneath the gas hydrate; drilling was halted because of safety concerns related to the gas. In contrast to well GC955-H, well GC955-Q found no gas hydrate in the shallower layers of fine-grained sediments. The third well, GC955-I, was drilled off of the main closure structure in an area predicted to include sand based on its proximity to the source channel, but anticipated to have lower gas hydrate saturation because of limited gas charge; this was confirmed by LWD data that indicate minimal gas hydrate. The LWD data and interpretations are described in detail by Guerin and others (2009), Boswell and others (2009), Collett and others (2012), and Boswell and others (2012b).

Our survey design at GC955 reflects the nature of the targets: an area approximately $4 \mathrm{~km}$ wide that is highly heterogeneous over scales as small as a few tens of meters. As such, our MCS transect 
spacing was as small as $50 \mathrm{~m}$, and our nominal OBS spacing was as small as $250 \mathrm{~m}$. MCS lines were oriented approximately north-south and east-west and they were similarly spaced in both directions to capture the three-dimensional geology. The OBS deployment pattern generally is 2D, but includes 10 instruments along the line that connects wells GC955-Q and GC955-H. The MCS lines are most concentrated in the area around wells GC955-Q and GC955-H, and some longer lines extend to the east to cross the channel feature that is described by Boswell and others (2009) and Boswell and others (2012b). We deployed an OBS at well GC955-I and included MCS transects crossing the well to tie in with the LWD data there. Augmenting the main grid of MCS transects was a set of lines up to $20 \mathrm{~km}$ long to provide long offsets and diverse azimuths for the OBS. In addition, we acquired MCS data along the transects targeted by earlier controlled-source electromagnetic (CSEM) surveys.

\section{Walker Ridge 313}

WR313 is located within the Terrebonne minibasin, approximately $300 \mathrm{~km}$ southwest of Cocodrie, La. The water depth is approximately $2,000 \mathrm{~m}$, and the main target layers extend to approximately 1,000 $\mathrm{m}$ below the seafloor (Frye and others, 2012; Boswell and others, 2012a). Predrilling analysis indicated later Neogene through Pleistocene sediments dipping at an average of about 10 degrees $\left(^{\circ}\right)$, with identified Pleistocene sand units being the main drilling targets based on seismic amplitude reversals at the inferred base of the gas hydrate stability zone (Hutchinson and others, 2009b; Boswell and others 2012a). Two JIP II wells were drilled at WR313, targeting these Pleistocene sand layers near their intersection with the base of gas hydrate stability (Guerin and others, 2009; Boswell and others, 2009; Collett and others, 2012).

Well WR313-G targeted a laterally extensive seismic amplitude anomaly within the so-called "blue" sand unit just updip of the position where its amplitude reverses at the inferred base of gas hydrate stability (Boswell and others, 2012a, 2012b; Frye and others, 2012). The LWD data confirmed a 21-m interbedded interval with $9 \mathrm{~m}$ (net) of sand with high gas hydrate saturation, as well as a shallower zone interpreted to contain considerable gas hydrate within fractures in fine-grained sediments. Well WR313-H was drilled approximately $1 \mathrm{~km}$ updip of well G, and targeted the so-called "orange" sand layer just updip of its intersection with the inferred base of gas hydrate stability. LWD data confirmed very high (up to 90 percent) gas hydrate saturations in the "orange" sand layer, and also indicated high gas hydrate saturation but limited sand thickness in the "blue" layer. In addition, WR313-H penetrated the same fracture-filling gas hydrates seen in well G in the shallower, fine-grained sediment layer. The WR313 LWD data and interpretations are described in detail by Guerin and others (2009), Boswell and others (2009), Boswell and others (2012b), Collett and others (2012), and Frye and others (2012).

Our survey design at WR313 reflects the geometry of the survey targets: generally 2D, with clear strike (approximately southwest-northeast) and dip (northwest) directions. Long (approximately $11 \mathrm{~km}$ ) and dense (as tightly spaced as $250 \mathrm{~m}$ ) MCS survey lines were oriented along the dip direction with sparser, shorter, cross-lines in the strike direction. The main dip line traced a series of amplitude anomalies observed in industry seismic data, intersected the WR313-H well, and extended downdip past the location where shallow hydrate-containing layers intersect the base of gas hydrate stability. OBS were deployed in a linear transect along the main dip line at spacings of 400 to $800 \mathrm{~m}$, augmented by several additional instruments in the area near wells WR313-G and WR313-H. The study area extended updip just beyond the edge of the interpreted amplitude anomalies in the "blue" and "orange" sands, and southwest to the seafloor scarp where units of interest reach the seafloor. As with GC955, the main grid of MCS transects was augmented by a set of longer (up to $20 \mathrm{~km}$ ) shooting lines aimed primarily at providing long offsets and diverse azimuths for the OBS, and by MCS lines coincident with the prior CSEM surveys. 


\section{Cruise Planning}

\section{Scientific Planning}

Scientific planning for the 2013 cruise on the $R / V$ Pelican began with a thorough evaluation of the options for acquiring multicomponent seafloor seismic data at the GC955 and WR313 sites. Standard industry practice involving the high-precision placement of hundreds or thousands of OBS using ROVs provides many advantages, but it carries a considerable cost because of the logistical complexities of ROV usage and because of the common necessity of a seismic source vessel in addition to the OBS-deployment vessel. In addition, these acquisition crews rarely are prepared to acquire seasurface streamer data simultaneous and coincident with OBS data. As a result, we determined that the best approach would be a USGS-led seismic acquisition cruise involving an academic-style OBS deployment (tens of instruments deployed by strategic free-fall) accompanied by acquisition of highresolution $2 \mathrm{D}$ seismic streamer data. In addition to providing a wealth of new insight into the JIP II study sites, the data from this cruise could also help guide any possible future industry-style OBS acquisition that might be carried out at the sites.

Detailed scientific planning for the $2013 R / V$ Pelican cruise was carried out collaboratively by the DOE, BOEM, and USGS during late 2012 and early 2013. The USGS developed a cruise science plan and refined it through email and telephone discussions with BOEM and DOE scientists. In January 2013, chief scientists met with BOEM scientists at the New Orleans BOEM offices to view proprietary seismic data and to discuss final details of the science plan with BOEM experts.

\section{Operational Planning}

Operational planning was conducted during a period of many months by all involved groups. A key factor in the success of our operation was the detailed planning and abundant communication within each group and between the various involved groups (LUMCON, OBSIP, USGS). In February 2013, with major plans in place, a substantial subset of the shipboard party met in Woods Hole, Massachusetts, to finalize operational details and to address remaining questions.

The Gulf of Mexico is an area of active petroleum exploration and thus on-going seismic operations. Petroleum industry seismic work typically involves considerably greater seismic energy than our survey, and thus any industry seismic activities in our vicinity could potentially have a substantial negative effect on the quality of our acquired data. To avoid disruptions once at sea, we contacted all seismic acquisition groups likely to be working in the GC955 and WR313 areas to coordinate operations in advance. We determined that no crews were planning activities in the vicinity of GC955, but that two industry groups already were operating in the area of WR313 and were on a time-sharing basis to avoid contaminating data. These groups were forthcoming with us regarding their plans and were flexible with regard to our planned surveys. Through extensive communications in advance of the cruise and while at sea, we were able to substantially minimize mutual disturbance. While acquiring data at GC955, we truncated one seismic line and adjusted course for another to avoid disrupting the course of a transiting (not actively acquiring) seismic fleet towing long streamers. For the duration of our WR313 data acquisition, both seismic crews left the area and we were able to record comparatively clean data. We experienced some disturbance from a seismic crew at a distance of 50 to $100 \mathrm{~km}$, but overall fared much better than we would have without extensive prior communication. 


\section{Cruise Operations}

\section{Data Acquisition Instrumentation}

Seismic data acquisition during the $R / V$ Pelican cruise (designated field activity P-01-13-LA in the USGS system) utilized a set of interconnected instrumentation systems aboard the $R / V$ Pelican including differential global positioning system (GPS) navigation, high-pressure GI-gun acoustic sources, digital multichannel hydrophone streamer, 4-component OBS, and shipboard data recording and processing computers. Most of this equipment was placed onboard the $R / V$ Pelican at the LUMCON facility in Cocodrie during the 3-day mobilization period from April 16 to April 18, 2013. Navigation, data recording, and data processing computers were installed in the starboard-side wet lab on the main deck, and the GI-gun firing system was installed in the port-side dry lab. These computers were linked by a local area network. The Woods Hole Oceanographic Institute (WHOI) OBS van was secured on the aft deck along the starboard side, the USGS streamer winch was secured slightly port of center line near the stern, and the two leased air compressors on the port side (fig. 2). A 500-gallon diesel fuel tank for the compressors was placed port side on the 01 deck, above and slightly forward of the compressors. 


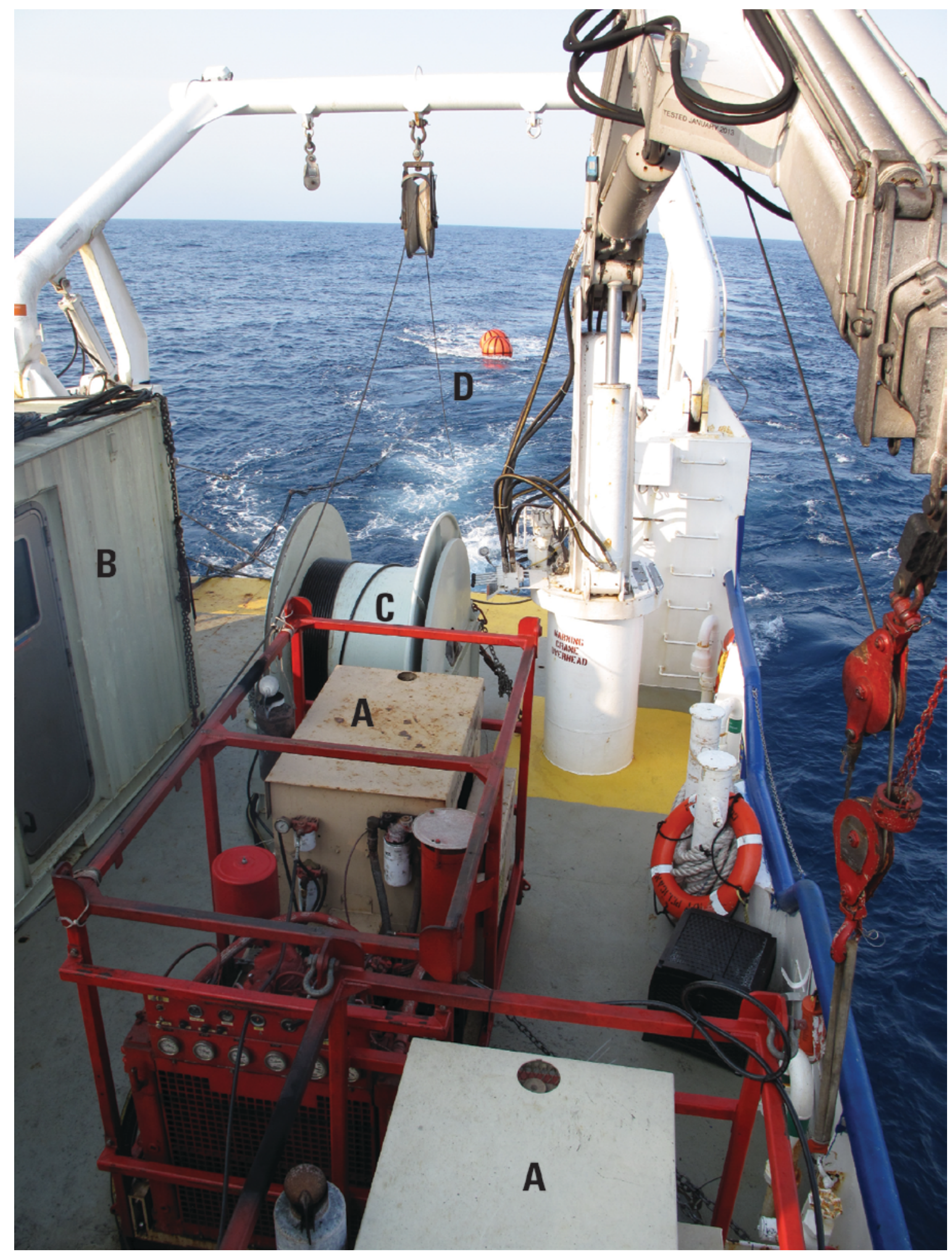

Figure 2. Photo of $R / V$ Pelican fantail from 01 deck during multichannel seismic data acquisition showing $A$, two portable compressors; $B$, rear of $\mathrm{OBS}$ van; $C$, hydraulic streamer winch; and $D$, GI-gun floats. Photograph courtesy of Rob Wyland, U.S. Geological Survey. 


\section{Navigation}

The $R / V$ Pelican shipboard differential GPS navigation system provided a standard GPS National Marine Electronics Association (NMEA) string to the wet lab for use by USGS navigation software and the MCS data logger. The GPS antenna was midships at a height of $15 \mathrm{~m}$ above the main deck and $18 \mathrm{~m}$ from the stern. Two navigation software programs recorded the GPS fixes and were used to display ship position during operations and for entering the pre-planned tracklines and OBS locations. All logged times were recorded as Julian Day (JD) and Greenwich Mean Time. HYPACK ${ }^{\circledR}$ commercial navigation software recorded GPS data during seismic data acquisition and a HYPACK ${ }^{\circledR}$ system monitor was set up in the wheelhouse to assist the crew in steering along tracklines selected by the science party in the wet lab. USGS Electronic Technicians Eric Moore and Tom O'Brien, and USGS Geophysicist Wayne Baldwin ran the HYPACK ${ }^{\circledR}$ system. YoNav software, developed at the USGS Pacific Coastal and Marine Science Center ran on a separate computer in the wet lab under the direction of USGS Electronics Technician Rob Wyland. YoNav recorded and displayed ship position continuously and was used for daily planning and monitoring progress. The MCS data recording system also received the GPS NMEA string and inserted coordinates into the seismic data file trace headers. Text and Google Earth .kmz files of the seismic tracklines and of the entire cruise can be viewed and downloaded from the USGS Infobank Web site at http://walrus.wr.usgs.gov/infobank/p/p0113la/html/p01-13-la.meta.html.

\section{Air Gun System}

GI-guns, manufactured by Seismic Systems, Inc., were used as the seismic source for the MCS and OBS data acquisition. Lamont-Doherty Earth Observatory Marine Operations loaned the USGS four GI 210 air guns for this project, to augment the one GI 210 air gun owned by the USGS. GI 210 air guns have a 105 -cubic-inch $\left(\mathrm{in}^{3}\right)$ generator chamber and a $105-\mathrm{in}^{3}$ injector chamber, totaling $210 \mathrm{in}^{3}$. Inserts can be placed inside the chambers to reduce their volume. "Harmonic mode" is the term used when a GI-gun is fired with equal volume in each chamber. "GI mode" refers to firing with an insert reducing the generator chamber volume to $45 \mathrm{in}^{3}$ and no insert in the injector chamber. GI mode provides more effective bubble-pulse reduction than harmonic mode, but source strength is diminished by the volume reduction.

During air gun operations, two GI-guns were towed in-line, separated by $2 \mathrm{~m}$ along a single 6-inch diameter concrete pump hose containing the electrical trigger lines and high-pressure air hoses. The guns were deployed using the A-frame winch of the $R / V$ Pelican and were suspended from two large buoys at a depth of approximately $3 \mathrm{~m}$ (fig. 3). The center point of the two guns was $22 \mathrm{~m}$ aft of the stern and $40 \mathrm{~m}$ aft of the GPS antenna. The guns could be fired simultaneously as a two-gun array or the triggers to one of the guns could be turned off if problems with the compressors limited the amount of available compressed air. The timing of the delay between the two air pulses was determined by a Hotshot air-gun firing system, built by Real Time Systems, that monitored the seismic source by way of a shot hydrophone attached to the GI-gun. Three GI-guns were kept ready as spares. The guns were configured in GI mode for most of the first 2 days of data acquisition, and were configured in harmonic mode ( $105-\mathrm{in}^{3}$ or $45-\mathrm{in}^{3}$ generator and injector chamber volumes) for the remainder of the cruise to maximize source power. The 105/105 harmonic configuration was used for a series of tracklines at each site that were intended to provide longer offsets to the OBS. The shot interval usually was $25 \mathrm{sec}$ for the two-gun array in 105/105 configuration and $10 \mathrm{sec}$ for two guns in a 45/45 configuration; these rates were chosen to maximize shot density with the available compressed air while allowing adequate listening time for the OBS and MCS data. 


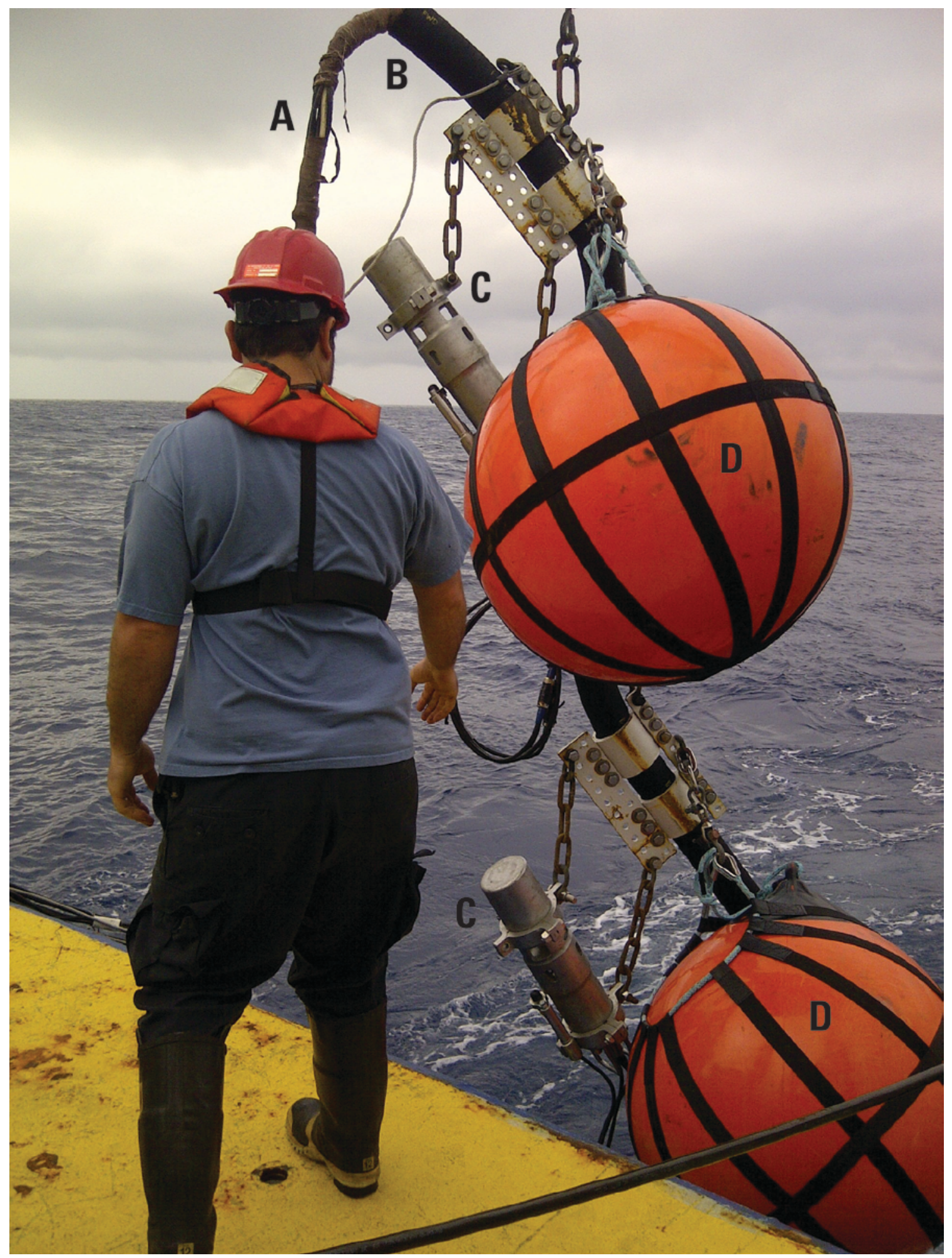

Figure 3. Pete Dal Ferro, USGS, supervising GI-gun deployment from R/V Pelican stern. $A$, Hose package containing trigger lines and high-pressure air hoses, passes through $B$, a 6 -inch diameter concrete pump hose that is connected to $C$, two $\mathrm{GI} 210$ air guns and $D$, gun float buoys. Photograph courtesy of Patrick Hart, U.S. Geological Survey. 
LUMCON leased two portable diesel air compressors for this program from Stark Industries, Houston, Texas, to supply 2,000 psi compressed air to the GI-guns. The two compressors supplied compressed air through regulators connected to a single manifold that delivered air by high-pressure hoses to the GI-guns. The compressors were rated to supply 100 standard cubic feet per minute (SCFM) each, but there were considerable mechanical problems with the compressors during seismic operations. One compressor was often shut down for repair, which meant that the GI-gun array had to be reduced at times from two guns to a single gun. These problems necessitated a spare parts delivery from Cocodrie by a hired sport fishing boat; the rendezvous was made $185 \mathrm{~km}$ (100 nautical miles) offshore during a detour in the transit from the GC955 site to the WR313 site. In general, the compressors achieved about 130 SCFM total. USGS Marine Technicians, Jenny White and Pete Dal Ferro, assisted by LUMCON Engineers, Sam Lebouef and Rodney Redman, ran the GI-gun and compressor operations.

\section{Shot Instant Data Logging}

Our GI-gun firing system included specially designed hardware for the purpose of obtaining shot times for the OBS data, in addition to triggering MCS data recording. GI-gun shots were triggered using a GPS-based clock that could be set to generate output triggers at any user-specified time interval. This clock would send the trigger signal to the Hotshot system, which in turn would send triggers to the GIgun solenoids. After a brief mechanical delay of a few tens of milliseconds, the GI-gun ports would open, and the generator chambers would discharge a sharp pulse of compressed air into the water, followed by the discharge of the injector chambers, creating the seismic source signal. The exact time of the onset of this pulse is the shot instant or $\mathrm{T}_{0}$ required for OBS interpretation and for initiation of recording of the multichannel streamer. Accurate interpretation of OBS data requires the absolute time of the shots to be known within a millisecond. Hydrophones, known as "shot phones," bolted to the bodies of the GI-guns, would sense the discharge pulse and send a signal back to the Hotshot system, which in turn would output a "field time break" (FTB) to a custom Arduino microcontroller board and also to the Geometrics multichannel Marine Controller software described below. The microcontroller board, designed and programmed by Thomas O'Brien of the USGS, was connected to the GPS clock that initiated the firing sequence and would take the exact GPS time of the FTB, accurate to approximately a nanosecond, and forward it to the HYPACK ${ }^{\circledR}$ navigation software to be logged in a text file.

\section{Hydrophone Streamer}

The USGS Coastal and Marine Geology Program (CMGP) owns a Geometrics GeoEel oil-filled digital hydrophone streamer including deck cable, tow cable, vibration damping, and stretch sections, and a GeoSpace depth-control bird system that were used for data recording during this cruise. The streamer includes nine 50-m sections, each with an analog-to-digital converter and eight channels at a $6.25-\mathrm{m}$ group spacing, resulting in 72 channels and $450 \mathrm{~m}$ of recording length. A computer set up in the wet lab recorded the streamer data using Geometrics Marine Controller software. The recording system was connected to the deck cable that, in turn, connected to the hydraulic streamer winch on the fantail 3 $\mathrm{m}$ from the stern. When deployed, the tow cable ran $55 \mathrm{~m}$ straight aft from the winch to a $10-\mathrm{m}$ vibration damping section, then the first active section. This geometry placed the near channel $62 \mathrm{~m}$ aft of the stern, $80 \mathrm{~m}$ aft of the GPS antenna, and $40 \mathrm{~m}$ aft of the center of the GI-gun array. At the tail end of the streamer, there was another $10-\mathrm{m}$ vibration section and then approximately $20 \mathrm{~m}$ of line to two tail-buoy floats. Three GeoSpace depth control birds were attached to the streamer (fig. 4); one each at the head, middle, and tail of the streamer. Streamer depth was controlled using software running on a computer in the wet lab. Initially, the birds were not able to consistently keep the streamer at the desired 
depth of $3 \mathrm{~m}$, but after adding several pounds of lead weight sheets to the streamer, depth could be accurately controlled. A back-up bird system was rented from ION Geophysical for this cruise but did not need to be deployed. Tom O'Brien and Eric Moore were in charge of the streamer and bird systems.

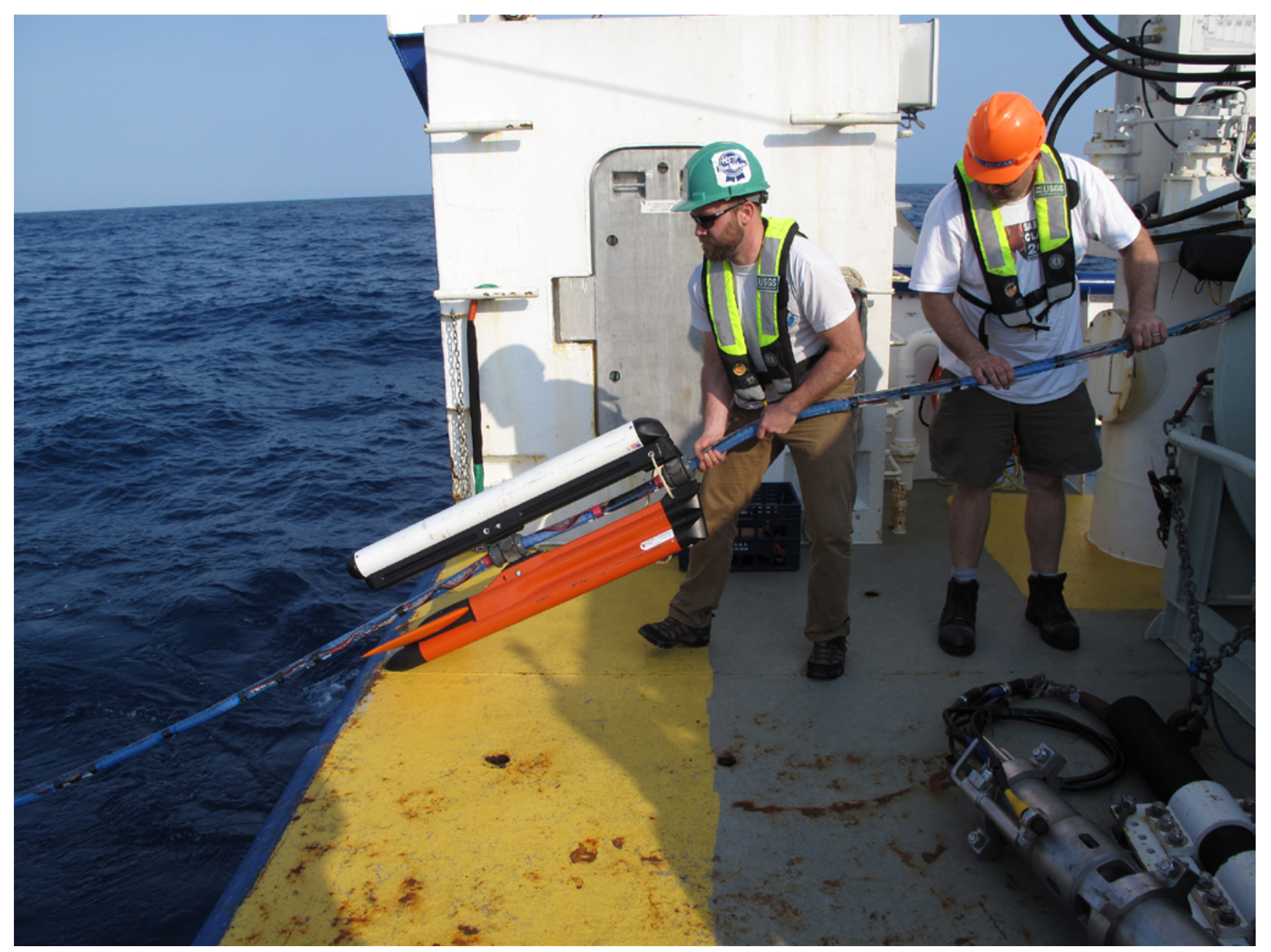

Figure 4. Eric Moore and Wayne Baldwin, USGS, retrieving GeoEel multichannel streamer with attached Geospace depth control bird. Photograph courtesy of Patrick Hart, U.S. Geological Survey.

\section{Woods Hole Oceanographic Institute Ocean-Bottom Seismometer}

The USGS, through its standing cooperative agreement with WHOI, arranged for use of 25 4component short period OBS from the Ocean Bottom Seismograph Instrument Pool (OBSIP) and for the services of two OBSIP OBS technicians, Peter Lemmond and Tim Kane. The USGS owns and pays to maintain 15 of these 25 instruments and makes them available for OBSIP to use in supporting academic cruises funded by the National Science Foundation when the USGS is not using them. The OBS were housed in a 20-foot (ft) by 8 -ft WHOI instrument van, which was loaded onto the $R / V$ Pelican using a rented high-capacity crane on the first day of equipment mobilization. Lemmond and Kane used the van as their shipboard lab for preparing OBS for deployment and downloading data from the OBS following recovery. All OBS deployments and recoveries were accomplished from the starboard side main deck using the ship's J-Frame (fig. 5). Twenty-one OBS were deployed at the GC955 site and all 25 were deployed at the WR313 site. 


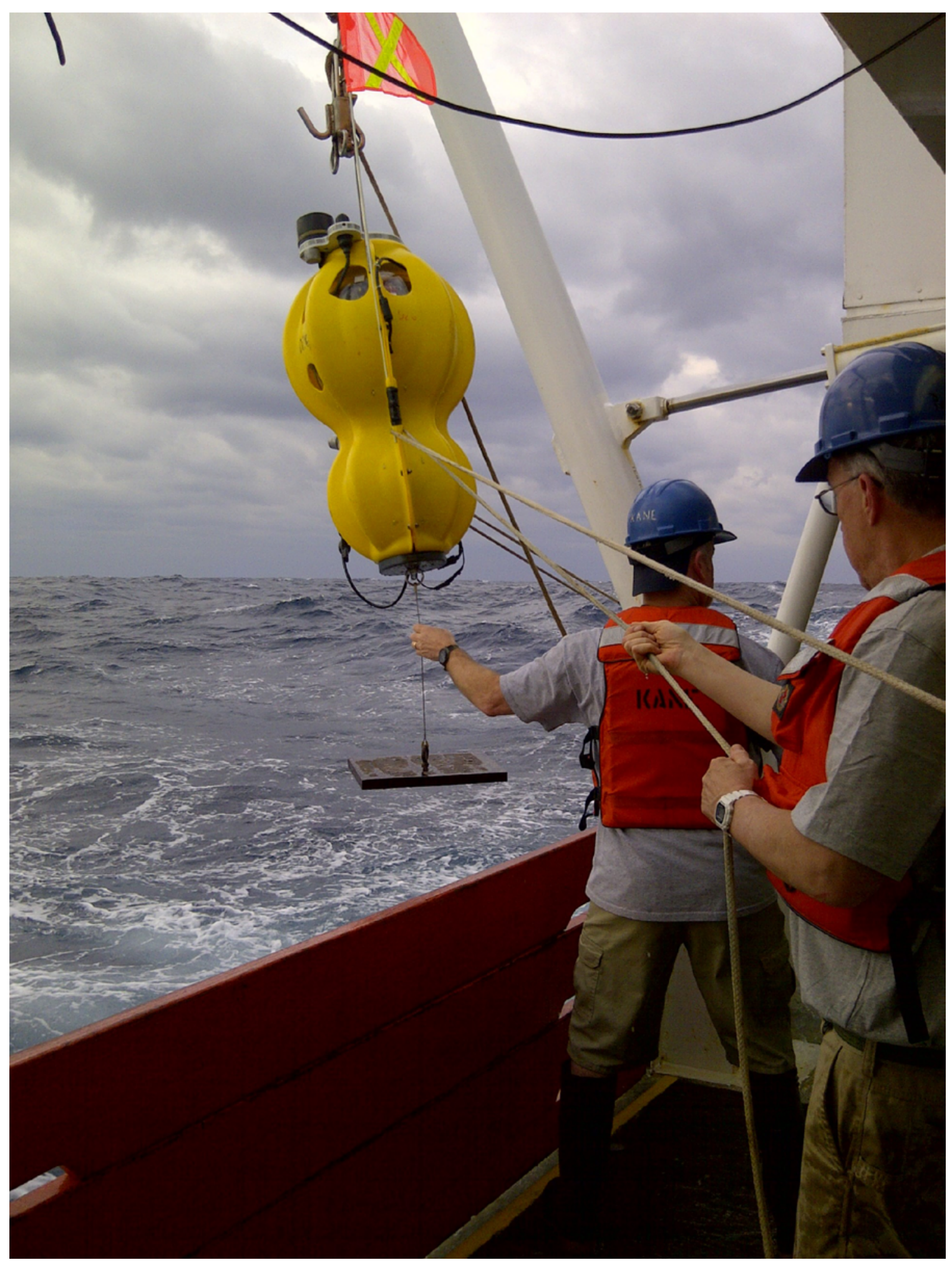

Figure 5. Tim Kane and Peter Lemmond, Woods Hole Oceanographic Institute, deploying OBS with attached anchor plate from R/V Pelican starboard-side main deck. Photo courtesy of Patrick Hart. 
We used OBS that are WHOI model D2, offering sample rates up to $200 \mathrm{~Hz}$. The instruments are equipped with EdgeTech transponders that allow limited communications with the ship by way of a $12-\mathrm{kHz}$ transducer and an EdgeTech deck box unit. From the time when an OBS is released until the time when it is given the command to cease communications, the transponder/transducer system serves as an acoustic range-finder, providing distance-to-OBS information to the shipboard crew. This provides a sign that the OBS is properly sinking, an indication of when it reaches the seafloor, and a means for determining the seafloor location of the instrument. For OBS communications, we used the $R / V$ Pelican's hull-mounted 12-kHz transducer and, as backup, an OBSIP-owned 12-kilohertz (kHz) transducer that was mounted on the ship's port-side instrument pole.

We deployed OBS by free-fall in carefully selected locations. With water depth of approximately $2000 \mathrm{~m}$, sink times were approximately 30 minutes and lateral drift was anticipated to potentially be as large as a few hundred meters. For the OBS positioned at the locations of the JIP II LWD boreholes, cruise science objectives dictated that we achieve OBS targeting accuracy no worse than a few tens of meters to achieve optimal tie-in between the LWD and OBS data. For this reason, we devised a deployment strategy for these key OBS: (1) deploy an OBS at the sea-surface position overlying the desired target location and wait for it to reach the seafloor, (2) steam around the instrument deployment location in a pattern with radius up to one-half of the water depth and spanning a range of azimuths, (3) determine the location of that OBS using the acoustic range measurement system of the OBS and commercial M-CAL software distributed by Software Engineering Associates (http://www.seanav.com/index.php? entry=nav-mcal), (4) calculate the associated drift distance and azimuth, and if necessary (5) deploy a second OBS in the updrift position from which the OBS was expected to reach its target based on the calculated drift distance and azimuth. In theory, the slowest parts of this process would be the OBS free-fall time and the ship's progress through the survey pattern; however, we determined quality control (identifying and discarding bad data points) and location determination using the M-CAL software to be quite time consuming, with the whole precision location approach taking between 1 and 3 hours. Using the ship's Acoustic Doppler Currect Profiler (ADCP) system, we determined currents to be generally homogeneous throughout each survey area and thus assumed that OBS drift would be consistent at each of the two study sites. Based on this assumption, we used the precision location approach for only the first instrument at each site (OBS station GC002 at well GC955-H, and WR001 at well WR313-G). We positioned subsequent OBS based on the drift indicated by the first OBS to maintain our deployment schedule. At GC955, we calculated negligible drift (35 m, on the order of the precision in the instrument location strategy), and at WR313 we calculated instrument drift of approximately $130 \mathrm{~m}$; these drifts were consistent with what we estimated using the ship's ADCP system.

For the nonprecision-located OBS, OBSIP personnel verified proper instrument response following deployment and sent the instrument the "disable communications" signal; we then proceeded to our next deployment location. Once acquisition was complete, we retrieved OBS by (1) returning to the instrument drop location and resuming communications through the acoustic system, (2) activating the anchor-release burn wire, (3) awaiting visual or VHF radio confirmation that the instrument was on the sea surface following approximately 30 minutes of rise time, and (4) retrieving the instrument through the starboard J-frame. Once on-board, each OBS was taken to the OBSIP van where the data were downloaded and clock corrections applied.

Before our return to port, OBSIP personnel cut the OBS data into receiver gathers and prepared SEG-Y data files for each of the survey transect lines. Shot times and locations were prepared for this purpose as described previously. USGS personnel left the ship with a complete set of SEG-Y data files for the GI-gun shots for both surveys. Complete OBS data records for the full recording duration were 
prepared post-cruise by OBSIP personnel and are hosted on the Incorporated Research Institutions for Seismology (IRIS) Data Management Center (http://www.iris.edu/dms/nodes/dmc). These data will be made available to the public following the customary waiting period.

\section{Multichannel Seismic Data Recording and Processing}

The digital multichannel streamer data were recorded in SEG-D format using PC-based Geometrics Marine Controller software. This software allows data quality monitoring of all channels on a shot-to-shot basis as well as a continuous display of any selected single channel. The recorded sample interval was $0.0005 \mathrm{sec}$, and the record length varied between 6 and $10 \mathrm{sec}$ depending on GI-gun configuration. SEG-D format records were each shot as a separate file, so the SEG-D shot files were grouped into a single directory for each line.

Wayne Baldwin, USGS Geophysicist, used SIOSEIS software (http://sioseis.ucsd.edu/sioseis.html) for shipboard processing of the raw SEG-D data files. Data for each line were combined into a single file, geographic coordinates for the shot and receiver locations added to the trace headers, the traces sorted from shot domain to common mid-point (CMP) domain, and SEG-Y format files of the CMP gathers output for post-cruise processing. Noise bursts on the data from other air gun operations near the WR313 site and from wave noise caused by high seas during the first few days at GC955 required noise spike editing steps. Normal-moveout velocity corrections were applied to the edited CMP gathers using velocity values supplied by Bill Shedd, BOEM, and the data were then stacked and migrated. These shipboard results were extremely useful for quality control and underway trackline planning and modification. (fig. 6). 


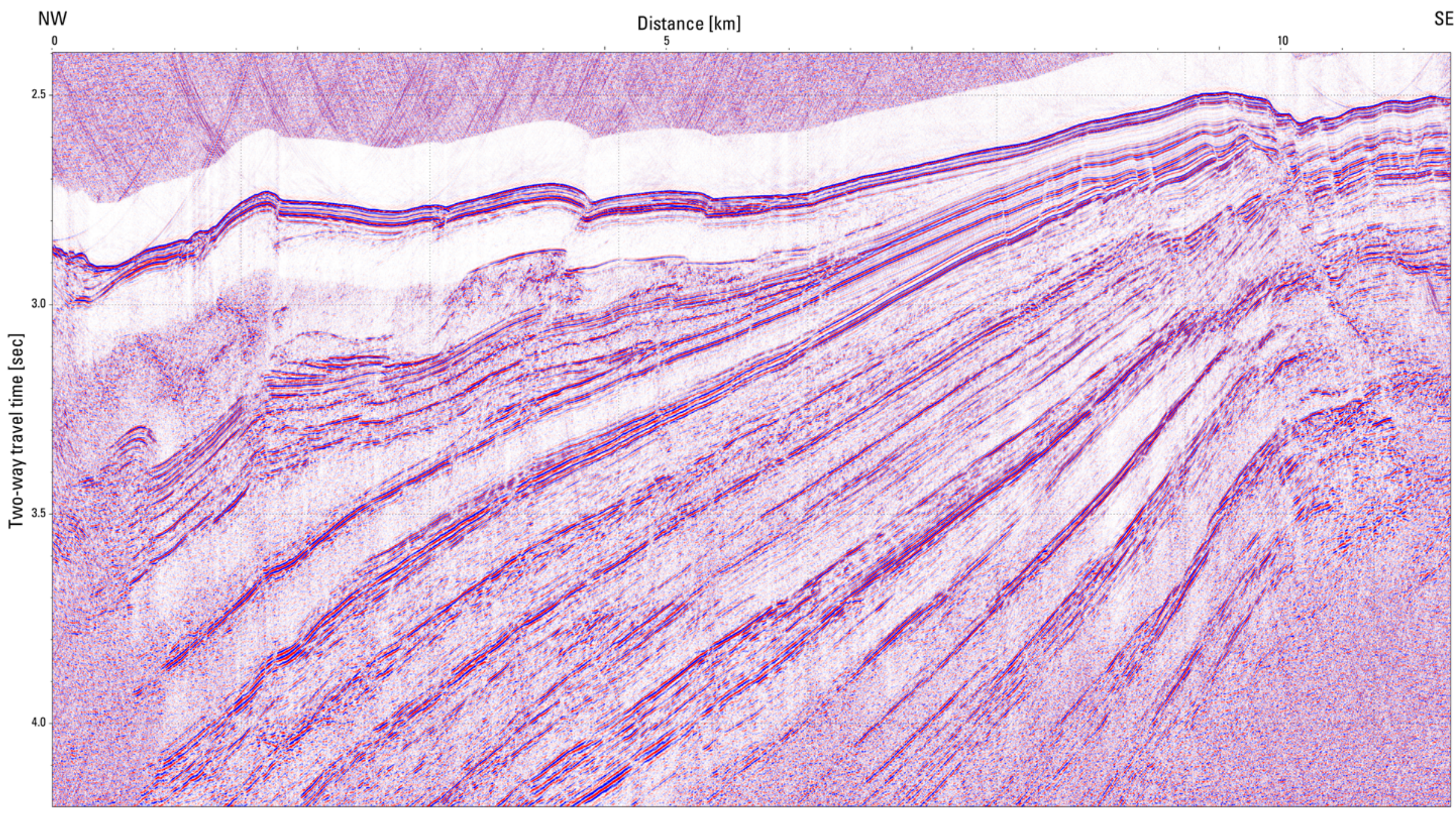

Figure 6. Shipboard processing of Walker Ridge 313 seismic line WR228. These data are shown, with interpretation, by Hart and others (2013). (sec, seconds, km, kilometers). 


\section{Daily Operations Summary}

Times noted are local (Cocodrie, La.) time. Dates are specified in standard month/day format, and also as JD.

Monday April 15 (JD 105)

All science crew arrived and stayed overnight onshore in Houma, La., during equipment mobilization of the $R / V$ Pelican. The OBS van was placed on the fantail using a rented high-capacity crane.

Tuesday April 16 (JD 106)

Mobilization began at LUMCON facility in Cocodrie, La. Two rental compressors arrived from Houston, Tex., and, along with the streamer winch, were placed on the fantail using the ship's crane.

Wednesday April 17 (JD 107)

All data acquisition and processing computers were set up in the ship's labs and connected with a local area network. Compressors were tested. The hired protected species visual observers (PSVO) were picked up at the New Orleans airport.

Thursday April 18 (JD 108)

Mobilization was completed and rental cars were returned. $R / V$ Pelican departure was delayed until 4 p.m. because of high seas at the Green Canyon site and to allow repair to the galley refrigerator.

Friday April 19 (JD 109)

Transit continued through the night and the $R / V$ Pelican arrived GC955 at 10:30 a.m. The first OBS deployment was delayed until afternoon because of 8-10-ft seas. Four OBS were deployed and at 10 p.m., operations were halted until Saturday morning because of continuing high seas.

Saturday April 20 (JD 110)

Calmer seas allowed deployment of 9 additional OBS during daylight to reach a total of 13. GIguns were deployed, tested, and retrieved for adjustment. The guns and streamer were deployed and MCS data acquisition began at 7:45 p.m. with a single gun in 45/105 GI mode.

\section{Sunday April 21 (JD 111)}

Twelve lines were acquired overnight. Seas improved, but data were noisy because of 4-6-ft seas and problems with the front of the streamer towing too close to surface. Streamer and GI-guns were retrieved at 7 a.m. Eight more OBS were deployed during daylight hours to reach a total of 21; no more OBS were deployed at GC955 to make up for time lost because of weather standby. Three pounds of lead were added to the front of the streamer to help with depth control and data acquisition resumed at 7 p.m. with a single gun in 45/105 GI mode. 
Monday April 22 (JD 112)

MCS data acquisition continued overnight. The USGS YoNav computer died at approximately 1 a.m.; YoNav software was installed on the $R / V$ Pelican shipboard computer and YoNav navigation logging resumed at $7 \mathrm{a} . \mathrm{m}$. The seas calmed substantially and streamer data were much less noisy although the front of streamer was still towing too shallow. Streamer and GI-guns were brought on board at approximately $(\sim) 11 \mathrm{a} . \mathrm{m}$. to allow servicing of the compressors and changing of gun configuration to two guns in 105/105 harmonic mode for acquisition of longer "spoke lines" shot primarily for OBS recording. Three pounds of lead were added to the streamer tail end and the tail buoy line was lengthened to help keep the streamer flatter and deeper. MCS gear was deployed and data acquisition resumed at $\sim 2$ p.m. There was a 20-minute shut down for dolphins at 4 p.m.

Tuesday April 23 (JD 113)

One GI-gun developed a leak at $\sim 1$ a.m., so MCS data acquisition continued with a single gun in 105/105 harmonic mode. Five long-offset "spoke lines" were completed by 6:30 a.m.; the GI-guns were retrieved, the leak in an air hose was repaired, and the configuration was changed to two guns in 45/45 harmonic mode. MCS acquisition resumed at 9:30 a.m. and continued through the day and into the night. There were intermittent problems with one compressor.

\section{Wednesday April 24 (JD 114)}

Thirty-seven MCS lines were acquired from 7 p.m. on Sunday to 3 a.m. on Wednesday when the streamer and GI-guns were pulled in to begin OBS recovery at 4 a.m. Of the 21 GC OBS, 9 were back on board by 4 p.m. More lead was added at several positions along the streamer, and MCS acquisition resumed at 7 p.m. with two guns in 45/45 harmonic mode configuration. The streamer was towing very flat at 3-m depth, seas were quite calm, and data quality was excellent although there were still mechanical problems with one of the compressors. Joe Malbrough, LUMCON Marine Superintendent, arranged to have a small boat bring spare compressor parts to rendezvous with the $R / V$ Pelican during the transit to the WR313 site.

\section{Thursday April 25 (JD 115)}

MCS data acquisition at GC continued through the night until 6 a.m., including reshooting several of the noisy lines from the first day of acquisition. OBS recovery resumed at 7 a.m., and the remaining 12 OBS were aboard by 6 p.m., at which time the transit to WR313 began.

\section{Friday April 26 (JD 116)}

Transit to Walker Ridge proceeded through the night and included a dogleg to the north to rendezvous with the spare parts delivery at a point $185 \mathrm{~km}$ (100 nautical miles) offshore. Parts and other supplies were transferred to the $R / V$ Pelican at $\sim 11$ a.m. Two OBS were deployed after arriving at the Walker Ridge site at $5 \mathrm{p} . \mathrm{m}$. Six more pounds of lead were added to the front of the streamer and MCS acquisition began at 7 p.m. with two GI-guns in 45/45 harmonic mode. Once data recording began, strong interference could be seen on the MCS data from air guns on an industry seismic vessel operating 50 to $100 \mathrm{~km}$ to the northwest. 
Saturday April 27 (JD 117)

The strength of the seismic interference from the nearby industry air guns varied through the night until MCS data acquisition ended at 3:30 a.m. At that point, OBS deployment resumed and continued until 4 p.m. with 13 more OBS deployed for a total of 15 . MCS data acquisition resumed at 5 p.m. with two GI-guns in 45/45 harmonic mode.

Sunday April 28 (JD 118)

MCS data acquisition continued until 4 a.m. and the remaining 10 OBS were deployed by 1 p.m., bringing the total to 25. MCS data acquisition resumed with two GI-guns in 45/45 harmonic mode. There were still intermittent compressor problems. Shipboard data processing indicated that much of the seismic interference from the nearby industry survey could be filtered out.

Monday April 29 (JD 119)

MCS data acquisition continued all night and through the day. Gun configuration was switched at 1 p.m. to two guns in 105/105 harmonic mode for shooting long-offset OBS "spoke lines."

Tuesday April 30 (JD 120)

MCS data acquisition continued until 6 a.m. Six OBS were retrieved before resuming MCS acquisition of "spoke" lines at 3 p.m., continuing until Wednesday morning. The seas increased to $\sim 4-7$ $\mathrm{ft}$. The nearby industry seismic operations ceased around 12 a.m..

Wednesday May 1 (JD 121)

Thirteen more OBS were retrieved beginning at 4 a.m., leaving six still in the water. The final session of MCS acquisition began at 5 p.m. and continued through the night with two guns in 105/105 harmonic mode. The seas calmed and data quality was excellent, especially without the nearby industry air gun interference.

Thursday May 2 (JD 122)

MCS acquisition ended at $\sim 2$ a.m., the remaining six OBS were on board by 10:30 a.m., and transit back to Cocodrie began. Most of the USGS computer gear was disconnected and packed during the transit.

Friday May 3 (JD 123)

The $R / V$ Pelican arrived at LUMCON in Cocodrie at 6 a.m. and all the heavy pieces of deck equipment and OBS van were craned off by 12 p.m.. All gear was packed and shipped by 3 p.m., and the cruise officially was completed.

\section{Environmental Compliance}

USGS seismic operations on the $R / V$ Pelican were conducted under the auspices of an Incidental Harassment Authorization (IHA) issued by the National Marine Fisheries Service (NMFS) to comply with the Marine Mammal Protection Act (MMPA) and a biological opinion issued by National Oceanic and Atmospheric Administration (NOAA) Office of Protected Resources (OPR) to comply with the 
Endangered Species Act (ESA) and the Magnuson-Stevens Act (Essential Fish Habitat). The IHA and biological opinion are henceforth referred to as "permitting documents."

In late 2012, the USGS submitted to NOAA a draft Environmental Assessment (EA) pursuant to the National Environmental Policy Act (NEPA), an IHA application (IHAA), and a request for ESA Section 7 consultation. The draft EA and IHAA were prepared for the USGS Gas Hydrates Project under a contract to LGL, Ltd., which has prepared similar documentation for high-energy seismic cruises carried out by the National Science Foundation (NSF). The draft EA and IHAA prepared for this cruise were the first in the U.S. marine research community to tier off and to fully incorporate by reference the "NSF-USGS Programmatic Environmental Impact Statement" on marine seismic research (National Science Foundation and U.S. Geological Survey, 2011; henceforth referred to as the "PEIS"). The PEIS was formulated between 2005 and 2011 by the NSF and USGS as action agencies and by NOAA as a cooperating agency. The PEIS included information about routinely used seismic sources, typical NSF and USGS seismic cruise operations, standard mitigation procedures, set exclusion radii for some sources, and the marine biology of representative operations areas. Because the USGS IHAA and EA for this cruise were formally tiered off the PEIS, these documents were substantially streamlined compared to similar documents that had been prepared for USGS and NSF seismic cruises in the previous 5 years.

The USGS signed its Record of Decision (ROD) fully implementing the PEIS on February 27, 2013, approximately 6 weeks before the $R / V$ Pelican cruise. The PEIS identified various scenarios for operating high- and low-energy air gun surveys, including those instances where marine mammal "takes" may or may not be anticipated. A marine mammal "take" is defined by the MMPA as an action "to harass, hunt, capture, collect, or kill, or attempt to harass, hunt, capture, collect, or kill any marine mammal" (50 Code of Federal Regulations §18.3; http://www.nmfs.noaa.gov/pr/glossary.htm). The 210$i^{3}$ GI-gun source fell within the PEIS criteria for low-energy sources; however, there was a reasonable expectation of takes during the cruise, and the decibels referenced to $1 \mu \mathrm{Pa}$ root-mean-square (dB re 1 $\mu \mathrm{Pa} \mathrm{rms}$ ) isopleth for a source of this volume is known to exceed a distance of $200 \mathrm{~m}$ from the source. Therefore, in accordance with the PEIS and ROD, the USGS sought an IHA and initiated formal consultation with NMFS.

In response to the USGS IHAA, NOAA issued a notice of intent to issue an IHA to the USGS in the Federal Register and opened a 30-day public comment period. During the public comment period, written comments were received from private citizens, nongovernmental organizations (NGO), energy industry representatives, and the Marine Mammal Commission (MMC). The public comments and the formal responses are available at the NMFS IHA Web site at

http://www.nmfs.noaa.gov/pr/permits/incidental.htm.

Only a few of the public comments are summarized here. One issue raised by an NGO was concern about habitat for the Atlantic bluefin tuna (Thunnus thynnus), which conducts some of its lifecycle activities in the deepwater northern Gulf of Mexico. The MMC noted concerns related to mitigation procedures, sound source verification, and accounting for repeated survey lines in take calculations. A group representing the energy sector commented that, in their opinion, an IHA should not be necessary for the relatively small sources that the USGS planned to deploy. The USGS took into account these comments and others in the preparation of the revised EA. The USGS issued the revised EA and Finding of No Significant Impact (FONSI) on April 12, 2013.

NOAA granted the IHA to the USGS and issued the biological opinion on April 16, 2013. The IHA authorized no takes of mysticetes and taking of 0 to 259 individuals of various species of odontocetes. The full take authorization and all other compliance documents are available at the USGS 
Coastal and Marine Geology Program's environmental compliance Web site at http://woodshole.er.usgs.gov/project-pages/environmental_compliance/index.html.

The IHA also outlined various monitoring and mitigation procedures. Two PSVOs from RPS Group Plc. were hired to carry out required monitoring and marine animal logging duties during daylight hours, with one PSVO on duty at any given time. The $180 \mathrm{~dB}$ re $1 \mu \mathrm{Pa}(\mathrm{rms})$ exclusion zone was established at $70 \mathrm{~m}$ for the full 210 -in ${ }^{3}$ GI-gun source, and the IHA provided specific shutdown and ramp-up procedures for the GI-guns. RPS filed the NMFS-required final marine animal monitoring report on May 3, 2013. The only marine mammals seen during the cruise were $\sim 10$ pantropical spotted dolphins (Stenella attenuate) that rode the bow wave and caused a 19-minute-long shutdown at the GC955 site on April 22, 2013. The final PSVO report is available at the USGS environmental compliance Web site: http://woodshole.er.usgs.gov/project-

pages/environmental_compliance/index.html.

\section{Cruise Data Overview}

We acquired a total of approximately $394 \mathrm{~km}$ of MCS data at GC955, and recorded the same sources with 21 deployed OBS (figs. 7 and 8). We acquired approximately $445 \mathrm{~km}$ of MCS data at WR313, and recorded the same sources with 25 deployed OBS (figs. 9 and 10).

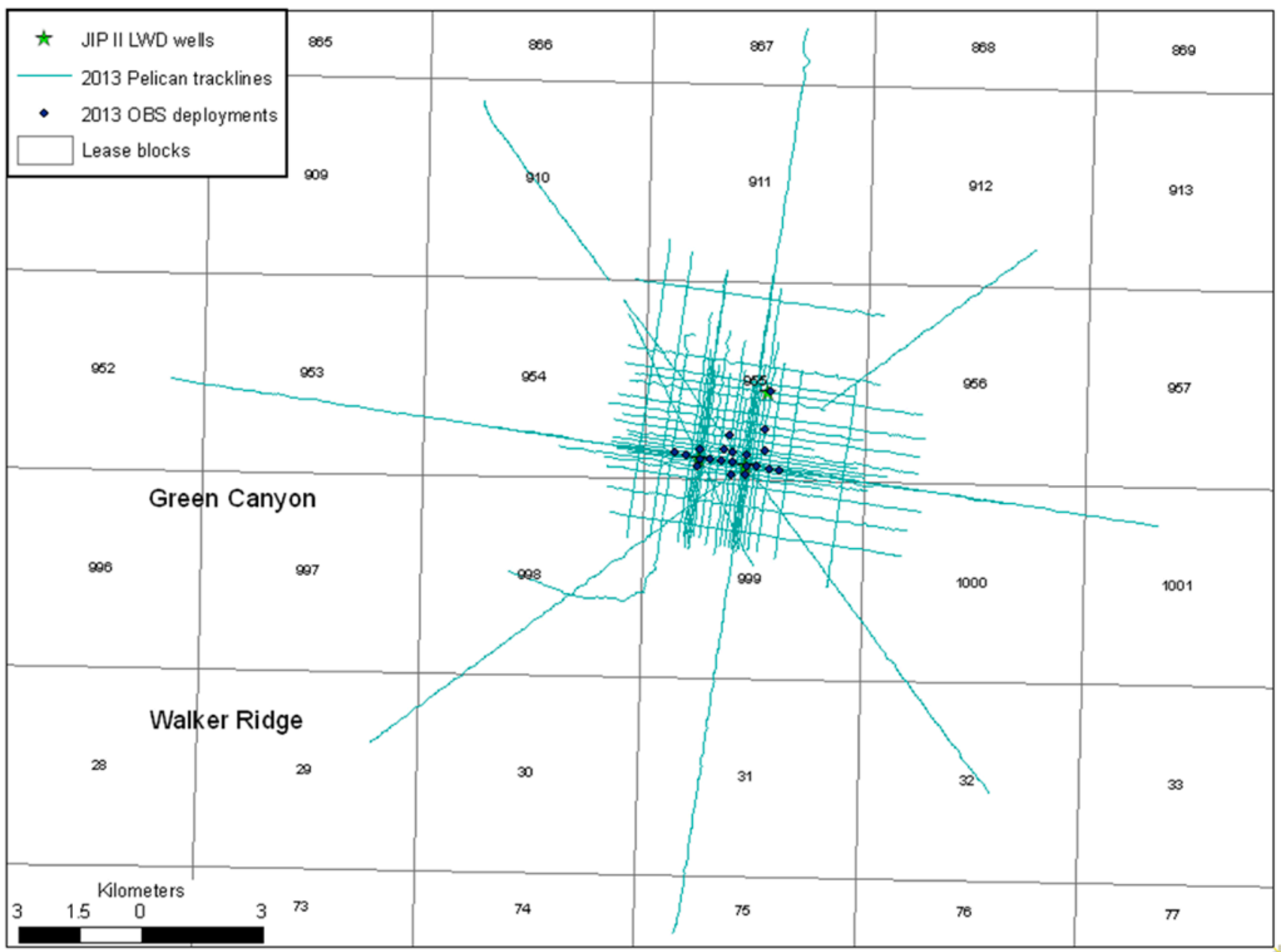

Figure 7. Map showing 2013 seismic transects and OBS deployments at GC955. 


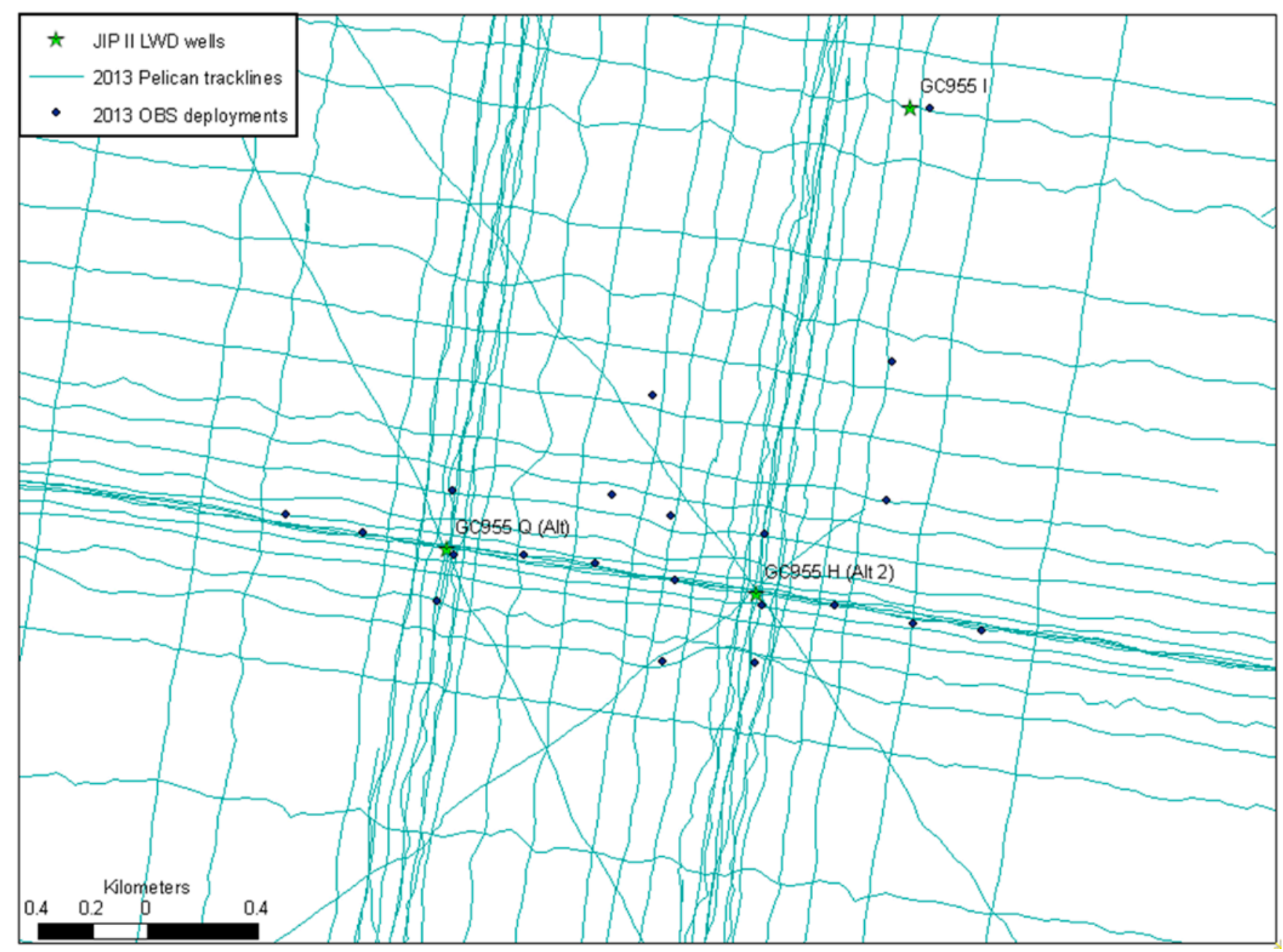

Figure 8. Zoomed map showing 2013 seismic transects and OBS deployments at GC955. 


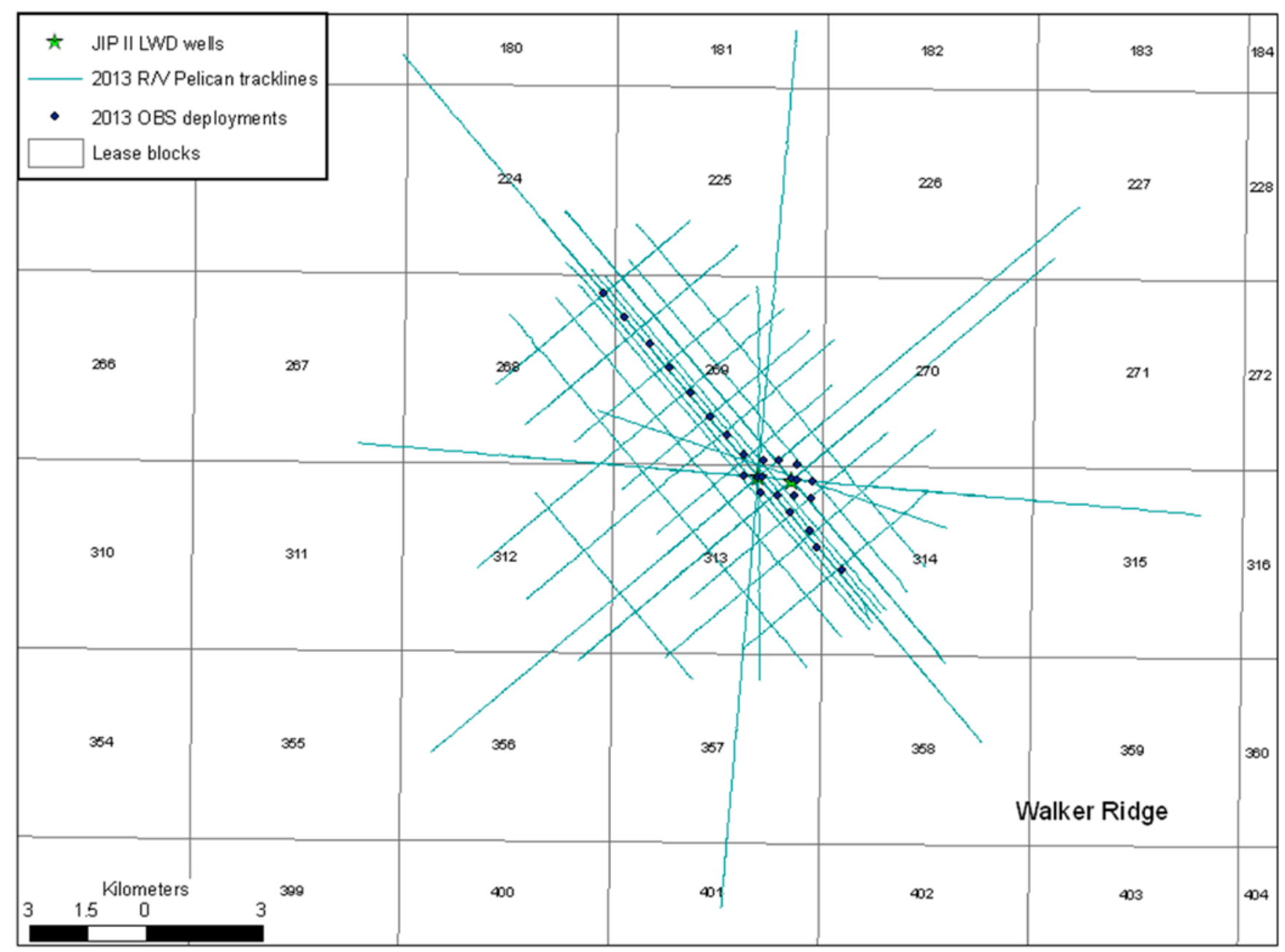

Figure 9. Map showing 2013 seismic transects and OBS deployments at WR313. 


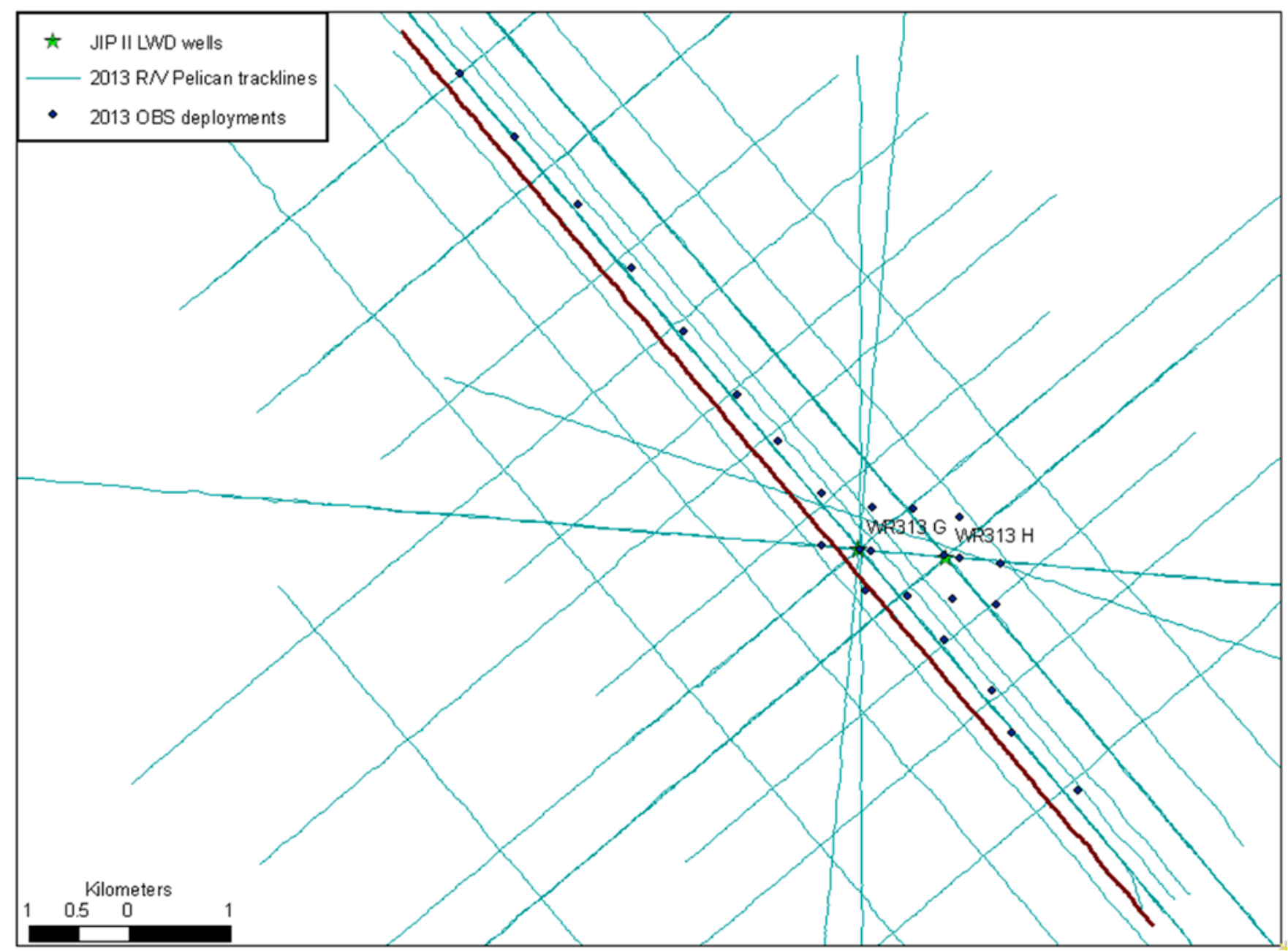

Figure 10. Zoomed map showing 2013 seismic transects and OBS deployments at WR313 including line WR228 in red for which processed data are shown in figure 6 .

MCS data processing is underway in the seismic group at the USGS Central Energy Resources Science Center in Denver, Colorado, and we are shifting to data interpretation activities in autumn 2013. The processed data will be archived at the USGS National Archive of Marine Seismic Surveys (http://walrus.wr.usgs.gov/NAMSS/), and will be made available to the public after the customary 2-year waiting period.

OBS data processing also is underway in the seismic group at the USGS Central Energy Resources Science Center in Denver. This process is a considerably more time-consuming process than MCS data processing so results will emerge over a longer time span. Raw continuous recording records are archived on the IRIS Data Management Center (http://www.iris.edu/dms/nodes/dmc) and the GIgun shot records will be archived in the same location. The continuous recording data will be made available to the public following a 2-year waiting period and the shot records will be released on a similar schedule. 


\section{Summary}

The U.S. Geological Survey led a seismic acquisition cruise in the Gulf of Mexico from April 18 to May 3, 2013, aboard the $R / V$ Pelican in order to acquire ocean-bottom seismometer and 2dimensional high-resolution multichannel streamer data at two gas hydrate study sites. In the area of block Green Canyon 955, we deployed 21 OBS and acquired approximately $400 \mathrm{~km}$ of streamer seismic data in a grid with line spacing as small as $50 \mathrm{~m}$ and along radial lines that provide source offsets up to $10 \mathrm{~km}$ and diverse azimuths for the OBS. In the area of block Walker Ridge 313, we deployed 25 OBS and acquired approximately $450 \mathrm{~km}$ of streamer seismic data in a grid pattern with line spacing as small as $250 \mathrm{~m}$ and along radial lines that provide source offsets up to $10 \mathrm{~km}$ for the OBS. These new data will provide valuable new information on the geology and gas hydrate systems at these two sites, and they will provide new insights regarding the use of geophysical methods for gas hydrate studies in other areas.

\section{Acknowledgments}

The U.S. Department of Energy and the U.S. Bureau of Ocean Energy Management provided financial support and scientific advice that made this research cruise possible. We very much appreciate the tireless efforts of the $R / V$ Pelican crew led by Captain Nicholas Allen, as well as the support provided by onshore LUMCON personnel led by Marine Superintendent Joe Malbrough. Shipboard operations were successful thanks to the seamless cooperation among all personnel-LUMCON, WHOI, RPS, and USGS - and we thank each member of these groups for their many contributions. We appreciate the expertise and advice provided by many scientists during pre-cruise science planning: Bill Shedd and Matt Frye (BOEM), Ray Boswell (DOE), Dan Lizarralde (WHOI), John Collins (WHOI OBSIP) and Tim Collett, Debbie Hutchinson, and Uri ten Brink (USGS). We thank Lamont-Doherty Earth Observatory Marine Operations for the loan of four GI-guns, and particularly Jeff Rupert and Tom Spoto for arranging the loan. We thank Mike Boyle (USGS Pacific Coastal Marine Science Center, Santa Cruz) for configuring the Hotshot system.

\section{References Cited}

Boswell, R., Collett, T., Frye, M., McConnell, D., Shedd, W., Dufrene, R., Godfriaux, P., Mrozewski, S., Guerin, G., and Cook, A., 2009, Gulf of Mexico Gas Hydrate Joint Industry Project Leg IITechnical Summary: Morgantown, W.V., U.S. Department of Energy National Energy Technology Laboratory, 26 p., accessed May 5, 2014, at http://www.netl.doe.gov/File\%20Library/Research/OilGas/methane\%20hydrates/TechSum.pdf.

Boswell, R., Collett, T.S., Frye, M., Shedd, W., McConnell, D.R., and Shelander, D., 2012a, Subsurface gas hydrates in the northern Gulf of Mexico: Marine and Petroleum Geology, v. 34, p. 4-30.

Boswell, R., Frye, M., Shelander, D., Shedd, W., McConnell, D., and Cook, A., 2012b, Architecture of gas-hydrate-bearing sands from Walker Ridge 313, Green Canyon 955, and Alaminos Canyon 21Northern deepwater Gulf of Mexico: Marine and Petroleum Geology, v. 34, p. 134-149.

Claypool, G.E., 2006, The Gulf of Mexico Gas Hydrate Joint Industry Project-Covering the cruise of the Drilling Vessel Uncle John, Mobile, Alabama to Galveston, Texas, Atwater Valley Blocks 13/14 and Keathley Canyon Block 151, 17 April to 22 May, 2005: Morgantown, W.V., U.S. Department of Energy National Energy Technology Laboratory, 196 p., accessed May 5, 2014, at

http://www.netl.doe.gov/File\%20Library/Research/OilGas/methane\%20hydrates/GOMJIPCruise05.pdf. 
Collett, T.S., 2005, Gulf of Mexico Gas Hydrate JIP Drilling Program downhole logging program, 65 p., in Claypool, G.E., ed., The Gulf of Mexico Gas Hydrate Joint Industry Project - Covering the cruise of the Drilling Vessel Uncle John, Mobile, Alabama to Galveston, Texas, Atwater Valley Blocks 13/14 and Keathley Canyon Block 151, 17 April to 22 May, 2005: Morgantown, W.V., U.S. Department of Energy National Energy Technology Laboratory, p. 12-76, May 5 2014, at http://www.netl.doe.gov/File\%20Library/Research/Oil-

Gas/methane\%20hydrates/GOMJIPCruise05.pdf.

Collett, T.S., Lee, M.W., Zyrianova, M.V., Mrozewski, S.A., Guerin, G., Cook, A.E., and Goldberg, D.S., 2012, Gulf of Mexico Gas Hydrate Joint Industry Project Leg II logging-while-drilling data acquisition and analysis: Marine and Petroleum Geology, v. 34, p. 41-61.

Cook, A., Guerin, G., Mrozewski, S., Collett, T.S., and Boswell, R., 2009, Gulf of Mexico Gas Hydrate Joint Industry Project Leg II-Walker Ridge 313 LWD operations and results: Morgantown, West Virginia, U.S. Department of Energy National Energy Technology Laboratory, 24 p., accessed May 5, 2014, at http://www.netl.doe.gov/File\%20Library/Research/OilGas/methane\%20hydrates/WR313LWDOps.pdf.

Dash, R., Spence, G., Hyndman, R., Grion, S., Wang, Y., and Ronen, S., 2009, Wide-area imaging from OBS multiples: Geophysics, v. 74, no. 6, p. Q41-Q47.

Frye, M., Shedd, W., and Boswell, R., 2012, Gas hydrate resource potential in the Terrebonne Basin, Northern Gulf of Mexico: Marine and Petroleum Geology, v. 34, p. 150-168.

Guerin, G., Cook, A., Mrozewski, S., Collett, T.S., and Boswell, R., 2009, Gulf of Mexico Gas Hydrate Joint Industry Project Leg II-Green Canyon 955 LWD operations and results: Morgantown, West Virginia, U.S. Department of Energy National Energy Technology Laboratory, 29 p., accessed May 5, 2014, at http://www.netl.doe.gov/File\%20Library/Research/OilGas/methane\%20hydrates/GC955LWDOps.pdf.

Hart, P.E., Haines, S., Ruppel, C., 2013, Seismic-Imaging Research Cruise Investigates Deepwater Gas Hydrate Deposits in the Gulf of Mexico: Santa Cruz, California, U.S. Geological Survey, accessed May 5, 2014, at http://soundwaves.usgs.gov/2013/08/.

Hutchinson, D., Boswell, R., Collett, T.S., Dai, J., Dugan, B., Frye, M., Jones, E., McConnell, D., Rose, K., Ruppel, C., Shedd, W., Shelander, D., and Wood, W., 2009a, Gulf of Mexico Gas Hydrate Joint Industry Project Leg II-Green Canyon 955 Site Selection: Morgantown, West Virginia, U.S. Department of Energy National Energy Technology Laboratory, 51 p., accessed May 5, 2014, at http://www.netl.doe.gov/File\%20Library/Research/Oil-

Gas/methane\%20hydrates/GC955SiteSelect.pdf.

Hutchinson, D., Boswell, R., Collett, T.S., Dai, J., Dugan, B., Frye, M., Jones, E., McConnell, D., Rose, K., Ruppel, C., Shedd, W., Shelander, D., and Wood, W., 2009b, Gulf of Mexico Gas Hydrate Joint Industry Project Leg II-Walker Ridge 313 Site Selection: Morgantown, West Virginia, U.S. Department of Energy National Energy Technology Laboratory, 35 p., accessed May 5, 2014, at http://www.netl.doe.gov/File\%20Library/Research/OilGas/methane\%20hydrates/WR313SiteSelect.pdf.

National Science Foundation and U.S. Geological Survey, 2011, Final Programmatic Environmental Impact Statement/Overseas Environmental Impact Statement for Marine Seismic Research Funded by the National Science Foundation or Conducted by the US Geological Survey: Washington, DC., National Science Foundation, 981 p., available at http://woodshole.er.usgs.gov/projectpages/environmental_compliance/reports/nsf-usgs-final-eis-oeis-with-appendices.pdf. 
Ronen, S.L., Comeaux, L., and Miao, J.G., 2005, Imaging downgoing waves from ocean bottom stations, in Annual Meeting of the Society of Exploration Geophysicists, 75, Houston, Tex., November 2005, Proceedings: Tulsa, Okla., Society of Exploration Geophysicists.

Ruppel, C., Boswell, R., and Jones, E., 2008, Scientific results from Gulf of Mexico gas hydrates joint industry project Leg 1 drilling - Introduction and overview: Marine and Petroleum Geology, v. 25, p. 819-829. 


\section{Appendix 1}

\section{Shipboard Personnel}

The members of the shipboard party are listed in the following table.

Table 1-1. The following individuals made up the shipboard party for cruise P1-13-LA.

[LUMCON, Louisiana Universities Marine Consortium; USGS, U.S. Geological Survey; OBS, ocean-bottom seismometer; OBSIP, Ocean-Bottom Seismometer Instrument Pool; WHOI, Woods Hole Oceanographic Institute.]

\begin{tabular}{lll}
\hline Name & Position & Institution \\
\hline Nicholas Allen & Captain & LUMCON \\
Tad Berkey & Chief Mate & LUMCON \\
Sam Lebouef & Chief Engineer & LUMCON \\
Rodney Redman & Assistant Engineer & LUMCON \\
Alex Ren & Marine Technician & LUMCON \\
Kendall Klay & Able-Bodied Seaman & LUMCON \\
Alex Forsythe & Chef & LUMCON \\
Patrick Hart & Chief Scientist & USGS \\
Seth Haines & Chief Scientist & USGS \\
Pete dal Ferro & Air gun Technician & USGS \\
Jenny White & Air gun Technician & USGS \\
Thomas O'Brien & Electronics Technician & USGS \\
Eric Moore & Electronics Technician & USGS \\
Ray Sliter & Geophysicist & USGS \\
Wayne Baldwin & Geophysicist & USGS \\
Robert Wyland & Electronics Technician & USGS \\
Peter Lemmond & OBS Technician & OBSIP/WHOI \\
Tim Kane & OBS Technician & OBSIP/WHOI \\
Jessica Richardson & Protected Species Visual Observer & RPS Group Plc. \\
Victoria Schaeffer & Protected Species Visual Observer & RPS Group Plc. \\
\hline
\end{tabular}




\section{Appendix 2}

\section{Seismic Transects Summary}

The seismic transect lines are listed in the following table.

Table 2-1. This table lists the seismic transect lines and provides some relevant information for each line. The entries in the "source array" column indicate the number of guns followed by the volume of the generator chamber and the volume of the injector chamber. Listed latitude and longitude values are for a WGS1984 projection.

[Line name suffixes indicate survey area: GC, Green Canyon (in and around GC955); WR, Walker Ridge (in and around WR313); km, kilometers.]

\begin{tabular}{|c|c|c|c|c|c|c|c|c|}
\hline $\begin{array}{l}\text { Line } \\
\text { name }\end{array}$ & $\begin{array}{c}\text { Julian } \\
\text { day }\end{array}$ & $\begin{array}{l}\text { Starting } \\
\text { longitude }\end{array}$ & $\begin{array}{l}\text { Starting } \\
\text { latitude }\end{array}$ & $\begin{array}{c}\text { End } \\
\text { longitude }\end{array}$ & $\begin{array}{c}\text { End } \\
\text { latitude }\end{array}$ & $\begin{array}{l}\text { Length } \\
(\mathrm{km})\end{array}$ & $\begin{array}{c}\text { Heading } \\
\text { (degrees) }\end{array}$ & $\begin{array}{c}\text { Source } \\
\text { array }\end{array}$ \\
\hline GC103 & 114 & -90.4525 & 26.9857 & -90.4430 & 27.0507 & 7.32 & 7 & $2 \times 45 / 45$ \\
\hline GC107 & 115 & -90.4383 & 27.0471 & -90.4476 & 26.9846 & 7.03 & 187 & $2 \times 45 / 45$ \\
\hline GC111A & 111 & -90.4781 & 26.9774 & -90.4448 & 26.9897 & 5.02 & 67 & $1 \times 45 / 105$ \\
\hline GC111B & 111 & -90.4446 & 26.9906 & -90.4369 & 27.0294 & 4.79 & 10 & $1 \times 45 / 105$ \\
\hline GC119 & 113 & -90.4340 & 27.0338 & -90.4414 & 26.9835 & 5.70 & 188 & $2 \times 45 / 45$ \\
\hline GC123 & 111 & -90.4348 & 27.0215 & -90.4402 & 26.9848 & 4.21 & 187 & $1 \times 45 / 105$ \\
\hline GC123A & 115 & -90.4342 & 27.0259 & -90.4402 & 26.9848 & 4.64 & 187 & $1 \times 45 / 45$ \\
\hline GC125 & 113 & -90.4340 & 27.0238 & -90.4400 & 26.9825 & 4.69 & 187 & $2 \times 45 / 45$ \\
\hline GC127 & 112 & -90.4306 & 27.0430 & -90.4370 & 27.0000 & 4.97 & 187 & $1 \times 45 / 105$ \\
\hline GC127A & 112 & -90.4388 & 26.9952 & -90.4393 & 26.9832 & 1.37 & 182 & $1 \times 45 / 105$ \\
\hline GC127B & 113 & -90.4306 & 27.0426 & -90.4392 & 26.9846 & 6.58 & 188 & $2 \times 45 / 45$ \\
\hline $\mathrm{GC} 127 \mathrm{C}$ & 115 & -90.4321 & 27.0327 & -90.4385 & 26.9894 & 4.87 & 187 & $2 \times 45 / 45$ \\
\hline GC129 & 111 & -90.4333 & 27.0210 & -90.4394 & 26.9797 & 4.71 & 188 & $1 \times 45 / 105$ \\
\hline GC129A & 115 & -90.4334 & 27.0205 & -90.4388 & 26.9839 & 4.12 & 188 & $2 \times 45 / 45$ \\
\hline GC131 & 113 & -90.4326 & 27.0222 & -90.4382 & 26.9847 & 4.26 & 188 & $2 \times 45 / 45$ \\
\hline GC135 & 113 & -90.4301 & 27.0297 & -90.4368 & 26.9845 & 5.26 & 188 & $1 \times 45 / 45$ \\
\hline GC139 & 115 & -90.4300 & 27.0204 & -90.4354 & 26.9829 & 4.22 & 187 & $2 \times 45 / 45$ \\
\hline GC143 & 115 & -90.4335 & 26.9817 & -90.4264 & 27.0288 & 5.31 & 8 & $2 \times 45 / 45$ \\
\hline GC145 & 113 & -90.4321 & 26.9834 & -90.4264 & 27.0221 & 4.80 & 7 & $2 \times 45 / 45$ \\
\hline GC147 & 115 & -90.4311 & 26.9835 & -90.4262 & 27.0156 & 3.76 & 8 & $2 \times 45 / 45$ \\
\hline GC151 & 111 & -90.4301 & 26.9836 & -90.4246 & 27.0207 & 4.46 & 8 & $1 \times 45 / 105$ \\
\hline GC153 & 111 & -90.4296 & 26.9830 & -90.4240 & 27.0198 & 4.30 & 8 & $1 \times 45 / 105$ \\
\hline GC153A & 115 & -90.4292 & 26.9855 & -90.4240 & 27.0201 & 3.90 & 8 & $2 \times 45 / 45$ \\
\hline GC155 & 112 & -90.4296 & 26.9846 & -90.4200 & 27.0441 & 7.36 & 8 & $1 \times 45 / 105$ \\
\hline GC155A & 113 & -90.4290 & 26.9835 & -90.4201 & 27.0422 & 6.99 & 8 & $2 \times 45 / 45$ \\
\hline GC157 & 111 & -90.4284 & 26.9834 & -90.4232 & 27.0194 & 4.20 & 7 & $1 \times 45 / 105$ \\
\hline GC157A & 115 & -90.4286 & 26.9839 & -90.4240 & 27.0132 & 3.31 & 8 & $2 \times 45 / 45$ \\
\hline GC159 & 112 & -90.4281 & 26.9830 & -90.4221 & 27.0231 & 5.04 & 8 & $1 \times 45 / 105$ \\
\hline GC161 & 115 & -90.4271 & 26.9827 & -90.4186 & 27.0400 & 6.67 & 8 & $2 \times 45 / 45$ \\
\hline
\end{tabular}


Table 2-1. This table lists the seismic transect lines and provides some relevant information for each line. The entries in the "source array" column indicate the number of guns followed by the volume of the generator chamber and the volume of the injector chamber. Listed latitude and longitude values are for a WGS1984 projection.-Continued

[Line name suffixes indicate survey area: GC, Green Canyon (in and around GC955); WR, Walker Ridge (in and around WR313); km, kilometers.]

\begin{tabular}{|c|c|c|c|c|c|c|c|c|}
\hline $\begin{array}{l}\text { Line } \\
\text { name }\end{array}$ & $\begin{array}{c}\text { Julian } \\
\text { day }\end{array}$ & $\begin{array}{c}\text { Starting } \\
\text { longitude }\end{array}$ & $\begin{array}{l}\text { Starting } \\
\text { latitude }\end{array}$ & $\begin{array}{c}\text { End } \\
\text { longitude }\end{array}$ & $\begin{array}{c}\text { End } \\
\text { latitude }\end{array}$ & $\begin{array}{c}\text { Length } \\
(\mathrm{km})\end{array}$ & $\begin{array}{c}\text { Heading } \\
\text { (degrees) }\end{array}$ & $\begin{array}{c}\text { Source } \\
\text { array }\end{array}$ \\
\hline GC165 & 113 & -90.4260 & 26.9821 & -90.4191 & 27.0282 & 5.23 & 7 & $1 \times 45 / 45$ \\
\hline GC169 & 115 & -90.4240 & 26.9823 & -90.4178 & 27.0237 & 4.67 & 8 & $2 \times 45 / 45$ \\
\hline GC175 & 113 & -90.4200 & 26.9810 & -90.4139 & 27.0220 & 4.63 & 8 & $2 \times 45 / 45$ \\
\hline GC187 & 115 & -90.4022 & 27.0183 & -90.4088 & 26.9735 & 5.04 & 187 & $2 \times 45 / 45$ \\
\hline GC203 & 114 & -90.4555 & 26.9904 & -90.3918 & 26.9808 & 6.50 & 100 & $2 \times 45 / 45$ \\
\hline GC207 & 111 & -90.4561 & 26.9961 & -90.3907 & 26.9863 & 6.71 & 99 & $1 \times 45 / 105$ \\
\hline GC211 & 112 & -90.4563 & 27.0007 & -90.3874 & 26.9905 & 7.12 & 99 & $1 \times 45 / 105$ \\
\hline GC215 & 112 & -90.4570 & 27.0025 & -90.4090 & 26.9955 & 5.03 & 99 & $1 \times 45 / 105$ \\
\hline GC217 & 112 & -90.4666 & 27.0050 & -90.3993 & 26.9950 & 6.98 & 99 & $1 \times 45 / 105$ \\
\hline GC221 & 114 & -90.4075 & 26.9971 & -90.4532 & 27.0039 & 4.64 & 279 & $2 \times 45 / 45$ \\
\hline GC223 & 114 & -90.4540 & 27.0045 & -90.4125 & 26.9983 & 4.23 & 99 & $2 \times 45 / 45$ \\
\hline GC225 & 112 & -90.3892 & 26.9953 & -90.4535 & 27.0048 & 6.57 & 279 & $1 \times 45 / 105$ \\
\hline GC225A & 114 & -90.3899 & 26.9954 & -90.4560 & 27.0053 & 6.69 & 280 & $2 \times 45 / 45$ \\
\hline GC227 & 114 & -90.4527 & 27.0051 & -90.4093 & 26.9987 & 4.41 & 99 & $2 \times 45 / 45$ \\
\hline GC229 & 112 & -90.4010 & 26.9981 & -90.4564 & 27.0062 & 5.67 & 279 & $1 \times 45 / 105$ \\
\hline GC233 & 112 & -90.3960 & 26.9984 & -90.4562 & 27.0071 & 6.12 & 279 & $1 \times 45 / 105$ \\
\hline GC235 & 114 & -90.4025 & 27.0001 & -90.4528 & 27.0075 & 5.12 & 279 & $2 \times 45 / 45$ \\
\hline GC237 & 112 & -90.3892 & 26.9990 & -90.4531 & 27.0086 & 6.53 & 280 & $1 \times 45 / 105$ \\
\hline GC241 & 114 & -90.4549 & 27.0108 & -90.4111 & 27.0042 & 4.45 & 100 & $2 \times 45 / 45$ \\
\hline GC245 & 112 & -90.4530 & 27.0121 & -90.3876 & 27.0027 & 6.69 & 99 & $1 \times 45 / 105$ \\
\hline GC249 & 112 & -90.4013 & 27.0065 & -90.4571 & 27.0146 & 5.70 & 279 & $1 \times 45 / 105$ \\
\hline GC253 & 112 & -90.4538 & 27.0164 & -90.3865 & 27.0065 & 6.88 & 99 & $1 \times 45 / 105$ \\
\hline GC261 & 111 & -90.4108 & 27.0133 & -90.4524 & 27.0194 & 4.26 & 279 & $1 \times 45 / 105$ \\
\hline GC265 & 112 & -90.4500 & 27.0209 & -90.3871 & 27.0117 & 6.43 & 99 & $1 \times 45 / 105$ \\
\hline GC269 & 114 & -90.4033 & 27.0160 & -90.4534 & 27.0234 & 5.08 & 279 & $2 \times 45 / 45$ \\
\hline GC273 & 111 & -90.4515 & 27.0268 & -90.3961 & 27.0186 & 5.70 & 99 & $1 \times 45 / 105$ \\
\hline GC287 & 111 & -90.3965 & 27.0337 & -90.4512 & 27.0418 & 5.60 & 279 & $1 \times 45 / 105$ \\
\hline GC302 & 113 & -90.4423 & 26.8985 & -90.4125 & 27.0973 & 22.31 & 8 & $1 \times 105 / 105$ \\
\hline GC312 & 112 & -90.3629 & 27.0477 & -90.4101 & 27.0131 & 6.07 & 231 & $2 \times 105 / 105$ \\
\hline GC312A & 113 & -90.4234 & 27.0033 & -90.5095 & 26.9398 & 11.12 & 230 & $2 \times 105 / 105$ \\
\hline GC321 & 112 & -90.5521 & 27.0200 & -90.4094 & 26.9984 & 14.39 & 100 & $2 \times 105 / 105$ \\
\hline GC321A & 112 & -90.3795 & 26.9940 & -90.3353 & 26.9873 & 4.46 & 100 & $2 \times 105 / 105$ \\
\hline GC321B & 113 & -90.3687 & 26.9924 & -90.4816 & 27.0092 & 11.39 & 280 & $1 \times 105 / 105$ \\
\hline GC331 & 113 & -90.4836 & 27.0803 & -90.4562 & 27.0410 & 5.16 & 148 & $1 \times 105 / 105$ \\
\hline GC331B & 113 & -90.4528 & 27.0366 & -90.3727 & 26.9286 & 14.47 & 147 & $1 \times 105 / 105$ \\
\hline GCCSEMA & 113 & -90.4251 & 26.9791 & -90.4524 & 27.0345 & 6.74 & 336 & $2 \times 45 / 45$ \\
\hline
\end{tabular}


Table 2-1. This table lists the seismic transect lines and provides some relevant information for each line. The entries in the "source array" column indicate the number of guns followed by the volume of the generator chamber and the volume of the injector chamber. Listed latitude and longitude values are for a WGS1984 projection.-Continued

[Line name suffixes indicate survey area: GC, Green Canyon (in and around GC955); WR, Walker Ridge (in and around WR313); km, kilometers.]

\begin{tabular}{|c|c|c|c|c|c|c|c|c|}
\hline $\begin{array}{l}\text { Line } \\
\text { name }\end{array}$ & $\begin{array}{l}\text { Julian } \\
\text { day }\end{array}$ & $\begin{array}{l}\text { Starting } \\
\text { longitude }\end{array}$ & $\begin{array}{l}\text { Starting } \\
\text { latitude }\end{array}$ & $\begin{array}{c}\text { End } \\
\text { longitude }\end{array}$ & $\begin{array}{l}\text { End } \\
\text { latitude }\end{array}$ & $\begin{array}{l}\text { Length } \\
(\mathrm{km})\end{array}$ & $\begin{array}{l}\text { Heading } \\
\text { (degrees) }\end{array}$ & $\begin{array}{c}\text { Source } \\
\text { array }\end{array}$ \\
\hline WR129 & 117 & -91.6674 & 26.6842 & -91.7076 & 26.6502 & 5.54 & 227 & $2 \times 45 / 45$ \\
\hline WR133 & 119 & -91.7042 & 26.6465 & -91.6635 & 26.6806 & 5.57 & 47 & $2 \times 45 / 45$ \\
\hline WR137 & 119 & -91.7249 & 26.6217 & -91.6536 & 26.6816 & 9.78 & 47 & $2 \times 45 / 45$ \\
\hline WR137A & 120 & -91.7246 & 26.6219 & -91.6542 & 26.6812 & 9.62 & 47 & $2 \times 105 / 105$ \\
\hline WR141 & 117 & -91.6989 & 26.6360 & -91.6536 & 26.6741 & 6.22 & 47 & $2 \times 45 / 45$ \\
\hline WR205 & 118 & -91.6995 & 26.6173 & -91.7358 & 26.6604 & 6.03 & 323 & $2 \times 45 / 45$ \\
\hline WR215 & 117 & -91.7409 & 26.7006 & -91.6724 & 26.6193 & 11.39 & 143 & $2 \times 45 / 45$ \\
\hline WR223 & 118 & -91.7303 & 26.7045 & -91.6644 & 26.6262 & 10.93 & 143 & $2 \times 45 / 45$ \\
\hline WR227 & 118 & -91.7250 & 26.7075 & -91.6580 & 26.6280 & 11.13 & 143 & $2 \times 45 / 45$ \\
\hline WR228 & 119 & -91.7281 & 26.7125 & -91.6578 & 26.6301 & 11.57 & 143 & $2 \times 45 / 45$ \\
\hline WR228A & 119 & -91.6580 & 26.6304 & -91.7248 & 26.7097 & 11.06 & 323 & $2 \times 45 / 45$ \\
\hline WR229 & 119 & -91.6577 & 26.6323 & -91.7286 & 26.7168 & 11.78 & 323 & $2 \times 45 / 45$ \\
\hline WR229A & 119 & -91.7293 & 26.7174 & -91.6563 & 26.6307 & 12.11 & 143 & $2 \times 45 / 45$ \\
\hline WR229B & 121 & -91.7306 & 26.7190 & -91.7131 & 26.6982 & 2.88 & 143 & $2 \times 105 / 105$ \\
\hline WR229C & 122 & -91.6586 & 26.6315 & -91.7285 & 26.7165 & 11.74 & 324 & $2 \times 105 / 105$ \\
\hline WR230 & 119 & -91.6561 & 26.6327 & -91.7227 & 26.7118 & 11.06 & 323 & $2 \times 45 / 45$ \\
\hline WR231 & 117 & -91.6548 & 26.6331 & -91.7197 & 26.7103 & 10.75 & 323 & $2 \times 45 / 45$ \\
\hline WR233 & 118 & -91.6535 & 26.6359 & -91.7187 & 26.7133 & 10.81 & 323 & $2 \times 45 / 45$ \\
\hline WR233A & 122 & -91.7281 & 26.7243 & -91.6474 & 26.6286 & 13.32 & 143 & $2 \times 105 / 105$ \\
\hline WR237 & 118 & -91.6499 & 26.6375 & -91.7142 & 26.7141 & 10.67 & 323 & $2 \times 45 / 45$ \\
\hline WR241 & 117 & -91.7116 & 26.7213 & -91.6450 & 26.6425 & 11.03 & 143 & $2 \times 45 / 45$ \\
\hline WR301 & 120 & -91.6752 & 26.7659 & -91.6926 & 26.5637 & 22.48 & 184 & $2 \times 105 / 105$ \\
\hline WR311 & 120 & -91.7591 & 26.6005 & -91.6093 & 26.7260 & 20.41 & 47 & $2 \times 105 / 105$ \\
\hline WR312 & 121 & -91.7038 & 26.6397 & -91.6149 & 26.7144 & 12.12 & 47 & $2 \times 105 / 105$ \\
\hline WR321 & 119 & -91.5823 & 26.6547 & -91.7767 & 26.6714 & 19.45 & 276 & $2 \times 105 / 105$ \\
\hline WR321N & 120 & -91.6204 & 26.6581 & -91.7410 & 26.6683 & 12.06 & 275 & $2 \times 105 / 105$ \\
\hline WR331 & 120 & -91.6411 & 26.6208 & -91.7286 & 26.7252 & 14.48 & 323 & $2 \times 105 / 105$ \\
\hline WR331A & 121 & -91.6417 & 26.6215 & -91.7211 & 26.7163 & 13.15 & 323 & $2 \times 105 / 105$ \\
\hline WR332 & 119 & -91.7655 & 26.7604 & -91.6320 & 26.6019 & 22.03 & 143 & $2 \times 105 / 105$ \\
\hline WR332A & 121 & -91.7333 & 26.7224 & -91.6424 & 26.6142 & 15.02 & 143 & $2 \times 105 / 105$ \\
\hline WR341 & 117 & -91.7441 & 26.6853 & -91.6994 & 26.7228 & 6.12 & 47 & $2 \times 45 / 45$ \\
\hline WR341A & 119 & -91.7412 & 26.6876 & -91.7027 & 26.7200 & 5.29 & 47 & $2 \times 45 / 45$ \\
\hline WR342 & 117 & -91.6893 & 26.7165 & -91.7322 & 26.6802 & 5.90 & 227 & $2 \times 45 / 45$ \\
\hline WR342A & 121 & -91.7372 & 26.6761 & -91.6924 & 26.7137 & 6.11 & 47 & $2 \times 105 / 105$ \\
\hline WR343 & 117 & -91.7261 & 26.6719 & -91.6856 & 26.7059 & 5.56 & 47 & $2 \times 45 / 45$ \\
\hline WR344 & 118 & -91.7483 & 26.6430 & -91.6775 & 26.7026 & 9.72 & 47 & $2 \times 45 / 45$ \\
\hline
\end{tabular}


Table 2-1. This table lists the seismic transect lines and provides some relevant information for each line. The entries in the "source array" column indicate the number of guns followed by the volume of the generator chamber and the volume of the injector chamber. Listed latitude and longitude values are for a WGS1984 projection.-Continued

[Line name suffixes indicate survey area: GC, Green Canyon (in and around GC955); WR, Walker Ridge (in and around WR313); km, kilometers.]

\begin{tabular}{lcccccccc}
\hline \multicolumn{1}{c}{$\begin{array}{c}\text { Line } \\
\text { name }\end{array}$} & $\begin{array}{c}\text { Julian } \\
\text { day }\end{array}$ & $\begin{array}{c}\text { Starting } \\
\text { longitude }\end{array}$ & $\begin{array}{c}\text { Starting } \\
\text { latitude }\end{array}$ & $\begin{array}{c}\text { End } \\
\text { longitude }\end{array}$ & $\begin{array}{c}\text { End } \\
\text { latitude }\end{array}$ & $\begin{array}{c}\text { Length } \\
(\mathbf{k m})\end{array}$ & $\begin{array}{c}\text { Heading } \\
\text { (degrees) }\end{array}$ & $\begin{array}{c}\text { Source } \\
\text { array }\end{array}$ \\
\hline WR345 & 119 & -91.6724 & 26.6968 & -91.7157 & 26.6604 & 5.95 & 227 & $2 \times 45 / 45$ \\
WR345A & 121 & -91.6724 & 26.6968 & -91.7157 & 26.6604 & 5.95 & 227 & $2 \times 105 / 105$ \\
WR346 & 118 & -91.6668 & 26.6947 & -91.7377 & 26.6352 & 9.72 & 227 & $2 \times 45 / 45$ \\
WR347 & 118 & -91.6434 & 26.6741 & -91.7057 & 26.6216 & 8.57 & 227 & $2 \times 45 / 45$ \\
WR348 & 117 & -91.6455 & 26.6594 & -91.6878 & 26.6235 & 5.84 & 226 & $2 \times 45 / 45$ \\
WRCSEMA & 118 & -91.7203 & 26.6785 & -91.6399 & 26.6516 & 8.61 & 111 & $2 \times 45 / 45$ \\
WRCSEMB & 119 & -91.6841 & 26.7070 & -91.6836 & 26.6161 & 10.11 & 180 & $2 \times 45 / 45$ \\
\hline
\end{tabular}

